\title{
Ganga River Water Quality Assessment using Combined Approaches: Physico-Chemical Parameters and Cyanobacterial Toxicity Detection with Special Reference to Microcystins and Molecular Characterization of Microcystin Synthetase (Mcy) Genes Carrying Cyanobacteria
}

VIGYA KESARI ( $\nabla$ vigya.kesari10@bhu.ac.in )

Banaras Hindu University https://orcid.org/0000-0003-0668-2340

Sanjay Kumar

IIT BHU: Indian Institute of Technology BHU Varanasi

Indrajeet Yadav

IIT BHU: Indian Institute of Technology BHU Varanasi

Antra Chatterjee

Banaras Hindu University Faculty of Science

Shweta Rai

Banaras Hindu University Faculty of Science

Shraddha Pandey

Banaras Hindu University Faculty of Science

Research Article

Keywords: Cyanobacteria, Microcystin synthase (mcy) genes, Microcystins, HPLC, PPIA, river Ganga, WQI

Posted Date: August 30th, 2021

DOI: https://doi.org/10.21203/rs.3.rs-518007/v1

License: @ (i) This work is licensed under a Creative Commons Attribution 4.0 International License. Read Full License

Version of Record: A version of this preprint was published at Environmental Science and Pollution Research on September 27th, 2021. See the published version at https://doi.org/10.1007/s11356-021-16589-1. 


\section{Abstract}

Water quality assessment relies mostly on physico-chemical based characterization however, eutrophication and climate change advocate the abundance of toxic microcystins (MCs) producing cyanobacteria as emerging bio-indicator. In the present study, a spatial-temporal analysis was carried out at ten sampling sites of Prayagraj and Varanasi during June 2017 and March 2018 to determine the Ganga River water quality using physico-chemical parameters, cyanobacteria diversity, detection of MCs producing strains and MC-LR equivalence. Coliform bacteria, $\mathrm{COD}, \mathrm{NO}_{3}-\mathrm{N}$ and phosphate are the significant contaminated parameters favoring the growth of putative MCs producing cyanobacteria. National Sanitation Foundation WQI (NSFWQI) indicates water quality, either bad or medium category at sampling points. The morphological analysis confirms the occurrence of diverse cyanobacterial genera such as Microcystis, Anabaena, Oscillatoria, Phormidium etc. PCR amplification affirmed the presence of toxic microcystin (mcy) genes in uncultured cyanobacteria at all the sampling sites. The concentration of MC-LR equivalence in water samples by protein phosphatase 1 inhibition assay (PPIA) and high-performance liquid chromatography (HPLC) methods was observed in the range of 23.4-172 ng/L and 13.2-97.5 $\mathrm{ng} / \mathrm{L}$ respectively which is lower than the harmful exposure limit by World Health Organization (WHO). Ganga isolate 1 was identified as Microcystis based on partial 16S rDNA sequence and its toxicity was confirmed due to presence of mcy genes and MCs production potential. These findings suggest the presence of MCs producers as new emerging parameter to monitor water quality index and identification up to species level will be valuable for restoration strategies of river Ganga.

\section{Introduction}

An emerging global problem is the scarcity of natural resources, especially the availability of clean water because of population growth and economic development. River water is a vital commodity to fulfill human's daily needs and for the development of sustainable economy. The Ganges is one of India's major rivers with length of 2,525 km originating from the Gangotri glacier of western Himalayas Uttarakhand, India (Tripathi and Singal 2019). The Ganga is sacred for its purity and self-cleansing property and its holy water plays a vital role in Hindu ceremonies starting from rituals of birth, initiation of marriage and death. However, it ranked among the world's five most polluted rivers due to anthropogenic activities and climatic fluctuations (Rai 2013; Dutta et al. 2020). As per the Central Pollution Control Board (CPCB), India (CPCB 2013; UPPCB 2019), cities situated along its bank i.e. from Kanpur to Varanasi are considered as the most polluted stream region. The intense cultivation to meet an ever-growing population's needs, encroachment of human activity and subsequent eutrophication due to excessive nutrient loading in water leads to the extinction of several species and vegetation (Sinha and Kannan 2014). Further, the discharge of untreated sewage, industrial wastes and inflow of agricultural runoff can be considered as major determinant for pollution in the river Ganga (Dixit et al. 2017; Siddiqui and Pandey 2019). Therefore, an accurate and rational assessment of Ganga water quality using physico-biochemical and molecular approaches is an essential prerequisite for determining the extent of its usefulness in everyday life.

Due to the role of algal abundance in determining the water quality in the freshwater ecosystems, cyanobacteria have been accepted as a major bioindicator of water pollution worldwide (Mateo et al. 2015; Casero et al. 2019). The toxic strains of cyanobacteria such as Microcystis, Planktothrix, Anabaena, Anabaenopsis, Nostoc, Oscillatoria, Aphanocapsa, Hapalosiphon, Fischerella, Gloeotrichia, Nodularia are the known producers of the hepatotoxic microcystins (MCs) (Kumar et al. 2020a; Wang et al. 2021). MCs are tumor promoter as they inhibit protein phosphatase type 1 and 2A in eukaryotes (Codd et al. 2005) and pose a significant health threat for drinking, irrigation water supplies and the environment at large (Turner et al. 2018; Massey et al. 2020). The biomagnification of MCs due to intake of the contaminated water by the plants and animals (fishes, water birds) will cause a potential health risk to animals and humans present at the higher trophic level (Chen et al. 2009). MCs are structurally cyclic heptapeptide synthesized by non-ribosomal pathway through multifunctional enzymes that include polypeptide synthetase and polyketide synthase modules (Neilan et al. 2013). Microcystin synthetase (mcy) gene cluster comprises $55 \mathrm{~kb}$ of DNA that includes 10 genes (mcyA-J) which are involved in the biosynthesis of MCs (Tillett et al. 2000) and essential for toxin production. The order of these ten mcy genes varies in cyanobacterial genera and their sequence similarities are also low (Genuário et al. 2010). More than 90 different MCs have been discovered based on degree of methylation, peptide sequence, hydroxylation and toxicity (Neilan et al. 2013). Although diverse communities of cyanobacteria are found in the river Ganga water, however, identification of toxigenic cyanobacteria that possess mcy genes as well as direct quantification of MCs are needed. Number of analytical techniques such as protein phosphatase inhibition assay (PPIA), enzyme-linked immunosorbent assay (ELISA), highperformance liquid chromatography (HPLC), mass spectrometry (MS) has been employed for the monitoring of different MCs in the contaminated water samples (Kumar et al. 2020a; Massey et al. 2020). Molecular technique such as polymerase chain reaction (PCR) based detection of $m c y$ genes ( $m c y$ A, $m c y B$, $m c y D, m c y E$ and $m c y G$ ) is rapid, cost-effective as well as facilitated the culture independent identification of toxic cyanobacteria in environmental samples (Genuario et al. 2010; Ribeiro et al. 2020). Numbers of studies were available on the assessment of river Ganga water quality based on physico-chemical parameters, bacterial and fungal diversity and metal toxicity (Behera et al. 2020; Matta et al. 2020; Prasad et al. 2020; Dimri et al. 2020). But so far, only one report has published that monitored the pollution in river Ganga in relation to the appearance of MCs producers (two strains isolated were named Oscillatoria sp. RBD01 and Leptolyngbya sp. RBD05) along with physico-chemical parameters from the highly polluted stretch i.e. Jajmau area of Kanpur city, Uttar Pradesh, India for the years 2013-2015. The Ganga water was found to be positive for MCs in the studied region with concentration $\geq 2$ ppb (Dixit et al. 2017).

Identification of MCs producing cyanobacteria in river Ganga has poorly monitored and under-appreciated as well as water pollution monitoring agencies do not mandate it's testing for water reserve quality assessment. Hence, at regular intervals, monitoring Ganga water quality parameters, including cyanobacterial toxicants evaluation, is an indispensable requirement to decrease the water originated threats. The present study is the first regional and spatial-temporal based assessment of cyanobacteria possessing mcy genes and its toxin (MC-LR equivalence) concentration in Ganga water at ten different sampling sites of Prayagraj and Varanasi regions of U.P., India, accompanied by various physico-chemical and biochemical parameters. The various cyanobacterial genera present in the water samples were visualized by microscopy. The presence of potentially toxic cyanobacteria in river Ganga at study sites was monitored by PCR amplification of mcy (mcyA, mcyB and mcyE) genes. Protein phosphatase 1 (PP1) inhibition assay (PPIA) and high-performance liquid chromatography (HPLC) methods were employed to determine MCs concentration in the water samples. At the molecular level, MCs covalently bind to and inhibit the activity of enzyme PP1 which lead to hyperphosphorylation of cellular proteins and increased the carcinogenic processes or cell death (MacKintosh et al. 1990). 
Furthermore, isolated cyanobacterium having mcy genes named Ganga isolate 1 was identified as belonging to the genus Microcystis by morphological and molecular analysis (16S rDNA sequence). The MCs production potential of isolated Microcystis under culture conditions was also evaluated. Thus, this study will provide essential baseline data across the Prayagraj and Varanasi regions of UP, India to comprehend the extent, magnitude and source of MCs to predict the trophic status of river Ganga.

\section{Materials And Methods \\ Study Area}

River Ganga passes through 29 cities, 70 towns and thousands of villages. The initial oligotrophic conditions in river Ganga changed over the next 25 years to eutrophic because of excessive nutrient loading (СРCB 2013; Dixit et al. 2017). In general, cyanobacteria have often been found to increase under eutrophic conditions. The present study was carried out at different sampling sites of Varanasi, a holy city of India, and Prayagraj, hosting the famous Kumbh Mela festival, situated on the river Ganga bank, Uttar Pradesh (U.P), India. The study area included the Gangetic stretch starting from Mehdhori Gaon Kachar (Prayagraj) to Ravidas mandir Ghat (Varanasi) with length of 130-135 km (Fig. 1) which is subjected to over-exploitation both in quantity and quality. There are various polluted drainage flows in the river Ganga from Prayagraj and Varanasi city along with more than 90 ghats with specific rituals. Indiscriminately discharged industrial effluents at Prayagraj and Varanasi regions affect physico-chemical and microbiological water quality which provides an excellent opportunity to reproduce several algal species including toxic cyanobacteria that can be used as water quality bio-indicators. Ten different sampling locations were carefully inspected and selected at Prayagraj and Varanasi regions to analyze phytoplanktonic water samples from the river Ganga depending upon the extent of pollution (Table 1). Global positioning system (Garmin, USA) was used to determine the 10-sampling site's geographical coordinates.

Table 1

Water sampling sites of river Ganga and their coordinates at Prayagraj and Varanasi.

\begin{tabular}{|llllll|}
\hline Prayagraj & & \multicolumn{4}{l|}{ Varanasi } \\
\hline Sampling sites & Latitude & Longitude & Sampling sites & Latitude & Longitude \\
\hline Allahabad Sangam (S1) & 25.423694 & 81.886056 & Dashashwamegh Ghat (S6) & 25.306222 & 83.016111 \\
\hline Daraganj Ghat area (S2) & 25.452611 & 81.889111 & Ramana Village Ghat (S7) & 25.233583 & 83.028583 \\
\hline Mehdhori Goan kachar(S3) & 25.498694 & 81.8475 & Ravidash mandir Ghat (S8) & 25.322778 & 83.031389 \\
\hline Rasoolabad Ghat (S4) & 25.504028 & 81.856278 & Samne Ghat (S9) & 25.27175 & 83.016111 \\
\hline Shastri Bridge Area (S5) & 25.435806 & 81.888389 & Sheetla Ghat (S10) & 25.316950 & 83.020670 \\
\hline
\end{tabular}

\section{Water Sampling}

Water samples were collected in prewashed and sterilized PTFE bottles (Tarsons, India) from the sampling sites of Prayagraj and Varanasi city (Table 1) for two years, once during June 2017 and another in March 2018. The top layer's water samples were collected within a depth of 40-50 cm for the physicochemical and biological parameters analysis as mentioned in Table 2. 10-20 L of top layer water samples was concentrated to approximately $50 \mathrm{~mL}$ in 100 $\mathrm{mL}$ sterilized vials using a phytoplanktonic net of mesh size $60 \mu \mathrm{m}$ and used for various biological analysis including algal cell density and concentration, uncultured cyanobacterial morphological evaluation, MCs producing cyanobacterial identification, MC-LR equivalence detection, isolation and characterization of MCs producing strains of cyanobacteria. A part of the concentrated water samples was fixed immediately with a Lugol's iodine solution (final concentration in sample 1\%) for morphological evaluation of the cyanobacteria and algal cell concentration estimation. The collected water samples were transported to the laboratory under low-temperature conditions.

Table 2. Physico-chemical and biological characteristics of water of the river Ganga at 10 different study sites of Prayagraj and Varanasi during two years (June 2017 and March 2018). Water characteristics have been compared with the permissible limit of various characteristics of drinking water. 


\begin{tabular}{|c|c|c|c|c|c|c|c|c|c|c|c|c|c|c|c|}
\hline \multirow[t]{3}{*}{ Parameters } & \multicolumn{10}{|c|}{ June 2017} & \multirow{2}{*}{\multicolumn{5}{|c|}{$\begin{array}{l}\text { March } 2018 \\
\text { Prayagraj }\end{array}$}} \\
\hline & \multicolumn{5}{|c|}{ Prayagraj } & \multicolumn{5}{|c|}{ Varanasi } & & & & & \\
\hline & s1 & S2 & S3 & S4 & S5 & S6 & s7 & S8 & s9 & S10 & s1 & S2 & S3 & S4 & S \\
\hline \multicolumn{16}{|l|}{ Physiochemical } \\
\hline Temperature $\left({ }^{\circ} \mathrm{C}\right)$ & 29 & 28 & 29 & 28 & 28 & 29 & 28 & 28 & 29 & 30 & 26 & 27 & 27 & 26 & 21 \\
\hline $\mathrm{pH}$ & 7.3 & 7.7 & 7.5 & 7.6 & 7.8 & 7.6 & 7.7 & 7.5 & 7.6 & 7.7 & 7.8 & 7.9 & 7.5 & 7.6 & 7. \\
\hline Conductivity (mho/cm) & 304 & 293 & 308 & 402 & 374 & 309 & 352 & 293 & 386 & 372 & 273 & 245 & 294 & 304 & 2: \\
\hline TSS(mg/L) & 89 & 142 & 118 & 123 & 80 & 102 & 62 & 135 & 124 & 96 & 96 & 167 & 108 & 156 & $7 i$ \\
\hline TDS(mg/L) & 257 & 289 & 343 & 320 & 261 & 309 & 285 & 321 & 298 & 310 & 221 & 209 & 275 & 298 & 2 \\
\hline Hardness(mg/L) & 284 & 301 & 290 & 212 & 289 & 210 & 194 & 298 & 217 & 313 & 374 & 290 & 294 & 192 & $2 i$ \\
\hline Alkalinity (mg/L) & 163 & 128 & 183 & 165 & 162 & 145 & 132 & 193 & 141 & 197 & 114 & 102 & 148 & 134 & 1: \\
\hline $\operatorname{Iron}(\mathrm{mg} / \mathrm{L})$ & 0.152 & 0.161 & 0.180 & 0.157 & 0.169 & 0.172 & 0.152 & 0.162 & 0.218 & 0.190 & 0.132 & 0.138 & 0.130 & 0.152 & 0. \\
\hline $\mathrm{NO}_{3}-\mathrm{N}(\mathrm{mg} / \mathrm{L})$ & 3.78 & 3.72 & 3.58 & 2.94 & 4.56 & 4.32 & 3.91 & 2.84 & 4.32 & 4.92 & 2.74 & 3.12 & 2.94 & 2.82 & 2. \\
\hline $\mathrm{COD}(\mathrm{mg} / \mathrm{L})$ & 41.2 & 32.8 & 48.4 & 50.7 & 43.9 & 44.2 & 54.3 & 50.2 & 43.6 & 41.4 & 37.2 & 33.3 & 36.2 & 39.4 & 41 \\
\hline Phosphate (mg/L) & 1.32 & 1.45 & 1.78 & 1.21 & 1.31 & 1.64 & 1.82 & 1.32 & 1.29 & 1.49 & 1.04 & 1.14 & 0.98 & 1.04 & 1. \\
\hline Sulphate (mg/L) & 46.5 & 40.0 & 49.0 & 45.2 & 41.0 & 52.0 & 37.4 & 45.2 & 40.4 & 50.2 & 36.2 & 32.3 & 39.5 & 37.2 & $3^{\prime}$ \\
\hline Chloride (mg/L) & 102 & 65 & 71 & 82 & 89 & 101 & 104 & 88 & 89 & 94 & 74 & 69 & 72 & 81 & 8: \\
\hline $\begin{array}{l}\text { Dissolved Oxygen } \\
\text { (mg/L) }\end{array}$ & 7.1 & 7.1 & 6.8 & 6.7 & 7.4 & 7.6 & 7.8 & 6.9 & 8.0 & 6.8 & 7.4 & 7.2 & 7.3 & 7.2 & 7. \\
\hline $\mathrm{BOD}_{5 \text { day }}(\mathrm{mg} / \mathrm{L})$ & 4.8 & 3.9 & 4.1 & 4.9 & 4.7 & 4.5 & 4.3 & 4.4 & 4.2 & 4.1 & 3.7 & 3.9 & 3.8 & 4.0 & 3. \\
\hline \multicolumn{16}{|l|}{ Biological } \\
\hline $\begin{array}{l}\text { Secchi transparency } \\
\text { depth }(m)\end{array}$ & 0.50 & 0.45 & 0.37 & 0.35 & 0.48 & 0.42 & 0.50 & 0.39 & 0.44 & 0.41 & 0.54 & 0.62 & 0.44 & 0.46 & 0 . \\
\hline $\begin{array}{l}\text { Algal cell conc. } \\
(\text { cells } / \mathrm{mL}) \times 10^{3}\end{array}$ & 8.1 & 9.0 & 9.3 & 10.2 & 10.7 & 10.1 & 9.7 & 8.7 & 8.3 & 9.2 & 7.3 & 7.1 & 6.4 & 6.8 & 5. \\
\hline $\begin{array}{l}\text { Algal cell density } \\
(\mathrm{mg} / \mathrm{L})\end{array}$ & 23.8 & 25.0 & 20.6 & 25.2 & 22.1 & 26.3 & 24.3 & 28.4 & 23.7 & 28.4 & 17.6 & 16.1 & 17.9 & 19.2 & $1 !$ \\
\hline $\begin{array}{l}\text { Total coliform } \\
\text { (MPN/100mL) } \times 10^{3}\end{array}$ & 7.6 & 8.9 & 10.3 & 11.3 & 9.3 & 10.3 & 8.2 & 9.5 & 11.3 & 11.2 & 6.2 & 5.3 & 7.3 & 6.9 & 8. \\
\hline $\begin{array}{l}\text { Fecal Coliform } \\
\left(\text { MPN/100mL) } \times 10^{3}\right.\end{array}$ & 4.0 & 5.3 & 6.1 & 7.2 & 4.8 & 7.1 & 4.9 & 5.2 & 8.1 & 7.2 & 3.1 & 3.5 & 4.0 & 4.4 & 3. \\
\hline $\begin{array}{l}\text { Chlorophyll a (mg/L) } \\
\times 10^{-2}\end{array}$ & 1.40 & 1.64 & 1.74 & 2.17 & 1.30 & 1.52 & 1.62 & 1.80 & 2.21 & 1.49 & 0.90 & 1.02 & 1.10 & 0.86 & 1. \\
\hline Productivity & 30.8 & 20.4 & 20.7 & 19.3 & 22.9 & 19.8 & 20.6 & 22.7 & 22.9 & 27.4 & 20.9 & 28.2 & 30.2 & 28.4 & 21 \\
\hline$\left(\mathrm{mgO}_{2} / \mathrm{m}^{2} / 24 \mathrm{~h}\right)$ & 12.3 & 11.4 & 12.9 & 9.5 & 10.2 & 13.0 & 10.3 & 11.5 & 11.9 & 12.7 & 10.4 & 14.6 & 11.2 & 13.2 & 1 . \\
\hline
\end{tabular}

Sampling sites-PRAYAGRAJ: (S1) Allahabad Sangam,(S2) Daraganj Ghat area, (S3) Mehdhori Gaon Kachar,(S4) Rasoolabad Ghat, (S5) Shastri Bridge area;VA mandir Ghat,(S9) Samne Ghat, (S10) Sheetla Ghat; GP - Gross Productivity; NPP-Net Primary Productivity. The each experiment were performed in triplicates a

\section{Physico-chemical And Biological Parameter Estimation Of Ganga Water Samples}

The physico-chemical and biological parameters for water samples were estimated using standard methods for examining water and wastewater (APHA 1998). Parameters such as conductivity, pH, temperature, transparency depth (Secchi disk), dissolved oxygen (DO), total dissolved solids (TDS) and productivity were estimated onsite. The algal cell concentration was counted by a haemocytometer using microscope. For primary productivity analysis, the "Light and Dark bottle" method was followed (Benton and Werner (1972)). Water samples were collected in triplicate between 10.00 am to 12.00 noon for DO analysis of initial, light and dark bottles. Experimental bottles (light and dark) incubated underwater in the euphotic zone for two hours by suspending it in 
water, after which dissolved oxygen content of each bottle was estimated (APHA 1998). Primary productivity estimated as oxygen equivalent was converted into carbon equivalent by multiplying it by the factor 0.375 (Sreenivasan 1964).

\section{Water Quality Index (Wqi)}

Water quality index of river Ganga was estimated using National Sanitation Foundation WQI (NSFWQI) method (Kamboj and Kamboj 2019) using eight different parameters $(Q)$ : $\mathrm{NO}_{3}-\mathrm{N}$, phosphate, TDS, $\mathrm{pH}$, temperature, $\mathrm{DO}$, fecal coliform and biochemical oxygen demand (BOD). The weight factor ( $W$ ) of these parameters is considered as $\mathrm{DO}-0.18$, fecal coliform $-0.17, \mathrm{pH}$ and $\mathrm{BOD}-0.12$, temperature, $\mathrm{NO}_{3}-\mathrm{N}$ and phosphate -0.11 and TDS -0.08 for river water quality. The $W Q I_{N S F}$ was calculated for each parameter by the following equation [i]:

$W Q I_{N S F}=?{ }_{k=1}^{n} W_{k} Q_{k}(\mathrm{i})$

where $n=$ number of water quality parameters; $Q_{k}=$ sub-index for $k^{\text {th }}$ water quality parameter; $W i=$ weight factor associated with $k^{\text {th }}$ water quality parameter.

The water quality rating scale projected was in the range of 0-100 and grading was performed as Excellent: 90-100, Good: 70-90, Medium: 50-70, Bad: 2550, and Very bad: $0-25$.

\section{Morphological Evaluation Of Cyanobacteria Of River Ganga}

Morphological evaluation of the cyanobacteria in collected phytoplanktonic water samples as well as Ganga isolates was carried under phase-contrast microscope (Nikon TE200) and photographed using a Zeiss Axioskop 60 optical light microscope equipped with an AxioVision LE 4.6 digital imaging system (Carl Zeiss, Jena, Germany).

\section{Molecular characterization of uncultured cyanobacteria in water samples of river Ganga Primer design for detection of cyanobacterial 16S rDNA and mcy genes}

PCR based molecular characterization was done using pair of primer set 27F1 and 781R1 specific for segment of cyanobacterial 16S rDNA (Jungblut et al. 2005). The specific mcyA-Cd primer pair was designed from a highly conserved region coding for the condensation domain of the mcyA gene that would allow the specific amplification from Microcystis, Planktothrix strains as well as other MC producing cyanobacterial genera (Hisbergues et al. 2003). For mcyB gene, the oligonucleotide primer set used in this study was designed by Mikalsen et al. (2003). To amplify the glutamate-activating adenylation domain of mcyE gene, primer pair was designed from general mcy gene E forward primer (mcyE-F2) and reverse primer (mcyE-R4), the genus-specific reverse primer for Microcystis (MicmcyE-R8), Planktothrix (PLAmcyE_R3) and Anabaena (AnamcyE-R12) (Rantala et al. 2004; Gobler et al. 2007). The specificity of each designed primer for mcy genes was verified by running BLASTn in the NCBI databases.

\section{Genomic DNA extraction and PCR amplification}

The presence of cyanobacteria having toxic mcy genes at ten sampling sites was investigated by PCR method using set of primers and strategies mentioned in Fig. 2. Genomic DNA extraction from the uncultured cells of phytoplanktonic Ganga water samples was performed according to the protocol of Srivastava et al. (2007). The concentration and purity of genomic DNA was checked by measuring absorbance at $260 \mathrm{~nm}$ and $\mathrm{A}_{260} / \mathrm{A}_{280}$ ratio in NanoVue Plus spectrophotometer (GE Healthcare Life Sciences) and was immediately kept at $-20^{\circ} \mathrm{C}$ for future purpose.

To PCR amplify the regions of genomic DNA targeting portion of the cyanobacterial 16S rRNA and mcy genes, seven primer pairs were used (Fig. 2). Each PCR reaction consists of $20 \mu \mathrm{l}$ that includes $20 \mathrm{ng} / \mu \mathrm{l}$ of template DNA, 1 x PCR buffer (GeNei Lab, India), $0.2 \mathrm{mM}$ each dNTPs (GeNei Lab, India), 5 pM of each primer and $0.05 \mathrm{U}$ of Taq polymerase (GeNei Lab, India). The reactions were performed in Mini Thermal Cycler (BioRad) programmed for 35 cycles. The initial denaturation step was at $94{ }^{\circ} \mathrm{C}$ for $5 \mathrm{~min}$. followed by 34 cycles of $94{ }^{\circ} \mathrm{C}(45 \mathrm{sec}), 50{ }^{\circ} \mathrm{C}(60 \mathrm{sec})$, and then $72{ }^{\circ} \mathrm{C}(90 \mathrm{sec})$. An additional cycle of final extension at $72{ }^{\circ} \mathrm{C}(10 \mathrm{~min})$ was used. The PCR products were electrophoresed in $1.5 \%$ agarose gels stained with ethidium bromide $(1 \mu \mathrm{g} / \mathrm{ml}) \mathrm{using} 1 \mathrm{x}$ TAE electrophoresis buffer ( $\mathrm{pH}$ 8.0). The sizes of amplified products were compared with the 100 bp DNA ladder (BR Biochem Life Sciences Pvt. Ltd.) to determine the size of amplified products. The gel was photographed in the G:BOX gel documentation system (Syngene, USA).

For further confirmation of microcystin synthase (mcyA, mcyB and mcyE) genes in uncultured cells, the PCR amplified products of the desired length were purified using QIAquick gel extraction kit (Qiagen). Blunt end DNA fragments (insert) generated were cloned in the pJET1.2/blunt cloning vector by CloneJET PCR Cloning kit (Thermo scientific). After ligation, the recombinant plasmids were transformed into $E$. coli strain DH5a (Novagen) and confirmed using colony PCR and subsequently by plasmid PCR. Recombinant plasmids harbouring mcyA, mcyB and generic mcyE genes were sequenced from GeNei Laboratories (India) for further phylogenetic studies. Each of the three mcy (mcyA, mcyB and generic mcyE) partial gene sequences obtained from this study were compared and analyzed using the reference sequences retrieved by BLASTn program available at GenBank and were aligned using ClustalW multiple sequence alignment. Phylogenetic tree analysis was performed using the Neighbour-Joining method based on the Kimura 2-parameter distance model. The tree robustness was estimated by bootstrap analysis based on 1000 resampling. The MEGA 6.0 program package was used for all the analyses (Tamura et al. 2013).

MC-LR equivalence detection

Page 5/19 
For MC-LR equivalence detection, the Ganga water samples collected in March 2018 from ten different study sites were frozen immediately or within one hour in lyophilized flasks of minimum $100 \mathrm{ml}$ volume and kept for lyophilization $\left(-70^{\circ} \mathrm{C}\right)$. The lyophilized residues were extracted with $70 \%$ methanol as described by Fastner et al. (1998). The supernatant of centrifuged samples was analyzed for MC-LR equivalence by the PPIA and HPLC methods.

\section{PPIA for MC-LR equivalence detection}

Pure MC-LR and protein phosphatase 1 (PP1) enzymes were obtained from ENZO Life Science (USA). HPLC grade methanol, dimethyl sulfoxide (DMSO) and p-nitrophenyl phosphate ( $p N P P$ ) were procured from Merck and HiMedia, respectively. The stock solution (1 g/L) of MC-LR was used for preparing the MC-LR working solution $(1 \mathrm{mg} / \mathrm{L})$ using methanol for the standard inhibition assay. The standard solutions of pure MC-LR was prepared from working solution in the concentration $0.01,0.1,1,5,10,100,200,300,500,1000 \mu \mathrm{g} / \mathrm{L}$ respectively in clean glass vials and used for dose-response inhibitory activity of MC-LR on PP1 using $p$-NPP substrate. The stock solution of purified PP1 enzyme was prepared by dissolving in DMSO (1 mg/mL;). The working concentration of PP1 enzyme $(1 \mu \mathrm{g} / \mathrm{mL})$ was prepared in buffer [50 mM Tris- $\mathrm{HCl}, 0.5 \mathrm{~g} / \mathrm{L} \mathrm{BSA}, 2 \mathrm{mM} \mathrm{MnCl} 2,0.1 \% \beta$-mercaptoethanol, $1 \mathrm{mM} \mathrm{Na}{ }_{2} \mathrm{EDTA}$, pH 7.4] to. The $p \mathrm{NPP}$ of 15 $\mathrm{mM}$ concentration was prepared in buffer containing $50 \mathrm{mM}$ Tris- $\mathrm{HCl}, 0.2 \mathrm{mM} \mathrm{MnCl}, 20 \mathrm{mM} \mathrm{MgCl} 2, \mathrm{pH} 8.1$.

The standard curve assay was carried out by adding $10 \mu \mathrm{L}$ each of pure MC-LR standard solution and PP1 enzyme working solution in a 96-well polystyrene microtitre plate. After pre-incubation for $1 \mathrm{~min}, 180 \mu \mathrm{L}$ of the substrate was added in a PP1 enzyme solution. The $p$-nitrophenol (pNP) production rate was estimated at $3 \mathrm{~min}$ interval for $21 \mathrm{~min}$ at $410 \mathrm{~nm}$ on a microtiter plate reader (Synergy, BioTek) at $28^{\circ} \mathrm{C}$. All enzymatic assays were performed in triplicate.

The assay for the test solution of MC was performed in a similar way as standard curve assay. Blank was prepared using a $10 \mu \mathrm{L}$ standard solution of pure MC-LR, $10 \mu \mathrm{L}$ enzyme dilution buffer and $180 \mu \mathrm{L}$ of $p$-NPP substrate. The positive control was investigated on the PP1 activity using a $10 \mu \mathrm{L}$ PP1 enzyme solution, $10 \mu \mathrm{L}$ methanol and $180 \mu \mathrm{L}$ of $p$-NPP substrate. For PPIA, the absorbance and PP1 enzyme kinetics profiles were obtained at $405 \mathrm{~nm}$ using the microtiter plate reader (Synergy, BioTek). The enzymatic reaction was performed at $37^{\circ} \mathrm{C}$ for $21 \mathrm{~min}(3 \mathrm{~min}$ of an interval).

\section{HPLC method}

HPLC analytical column C18, ODS $(25 \times 0.46 \mathrm{~cm}$ and $5 \mu \mathrm{m}$ particle size $)$ was used for MC-LR equivalence detection and the volume of samples injected was $100 \mu \mathrm{L}$. UV array detector attached to the HPLC system (Waters System, USA) was used for detection at $238 \mathrm{~nm}$. The column temperature was maintained at $30^{\circ} \mathrm{C}$ by column oven. Two mobile phases (acetonitrile and HPLC water) were applied with TFA $(0.05 \% \mathrm{v} / \mathrm{v})$ for detection. The applied analytical procedure was gradient run as follows: $0 \mathrm{~min}-20 \% \mathrm{~A}$ and $80 \% \mathrm{~B}, 8 \mathrm{~min}-60 \% \mathrm{~A}$ and $40 \% \mathrm{~B}, 15 \mathrm{~min}-20 \% \mathrm{~A}$ and $80 \% \mathrm{~B}, 25 \mathrm{~min}-20 \% \mathrm{~A}$ and $80 \% \mathrm{~B}$. The flow rate was kept at $1.0 \mathrm{~mL} / \mathrm{min}$. The standard calibration curve was used for the determination of the unknown concentration of MC-LR equivalence in samples.

\section{Isolation and characterization of MC producing cyanobacteria from river Ganga}

Isolation of cyanobacteria possessing mcy genes was attempted from river Ganga water samples using standard isolation protocol in BG-11 agar plate and liquid media. Phytoplanktonic water samples $(500 \mu \mathrm{l})$ were streaked on BG-11 agar $(1.5 \% \mathrm{w} / \mathrm{v})$ plates and incubated at $27 \pm 1{ }^{\circ} \mathrm{C}$ under the fluorescent light tubes emitting $72 \mu \mathrm{mol}$ photon $\mathrm{m}^{-2} \mathrm{~s}^{-1}$ light intensity with a photoperiod of 14:10 h. The cyanobacterial inoculum was transferred to the new BG-11 agar plates. The process was continued until single colonies of cyanobacterial strains were obtained. The purified isolates of cyanobacterial strain were re-cultured in BG-11 liquid media at similar conditions for 4-8 weeks. Preliminary identification of the isolated strains was based on morphological characters as observed under microscope which was further evaluated for the presence of mcy genes using PCR approach. The Ganga isolate possessing mcy genes was further estimated for its genetic identity and MC producing potential. For genetic identification of the Ganga isolate possessing mcy gene, partial $16 \mathrm{~S}$ rDNA sequence obtained was aligned and analyzed with reference sequences of different closely related cyanobacterial species retrieved from the GenBank database.

\section{Statistical Analysis}

The physico-chemical and biological parameters data of water samples were presented as mean values with standard deviation. For WQI analysis, descriptive statistics were applied. Box-whisker plot was used to describe the spatial-temporal variations of the observed water quality parameters of river Ganga.

\section{Results And Discussion}

River Ganga is the primary water source for wider communities in North India. Prayagraj and Varanasi cities are densely populated areas with intense agricultural activities therefore, the Gangetic water stretches in these regions are characterized by high nutrient inputs from the catchment and categorized as eutrophic (Kumar et al. 2020b). The statistics about the river Ganga surface water quality are crucial for various usages and preserving its aquatic life. So far, information about the distribution of MCs producing cyanobacteria is uncertain in Ganga water, which is essential to estimate the health risks associated with the cyanobacterial toxins. Taking recourse to above, the present study was executed to assess the river Ganga's surface water quality at ten different sampling sites in Prayagraj and Varanasi using various physico-chemical and biological characteristics. The monitoring approach for Ganga water further involves the detection of putative MCs producing cyanobacteria and its toxin MC-LR equivalence. Table 1 describes river Ganga's water sampling points and their geographical coordinates (latitude, longitude) at study sites.

\section{Physico-chemical and biological parameters of river Ganga water at Prayagraj and Varanasi}

The physico-chemical and biological parameters of river Ganga water at various sites of Prayagraj (sites: S1-S5) and Varanasi (sites: S6-S10) with their mean values were estimated and shown in Table 2. A total of 15 physico-chemical and 7 biological parameters were investigated for two years, i.e. June 2017 and March 2018, respectively. The study suggested both spatial and yearly variations in the physico-chemical and biological parameters. 


\section{Physico-chemical Parameters Analysis}

It is clearly depicted that (Table 2) the $\mathrm{pH}$ level ranges between 7.5 to 7.9 at all sampling sites during the study time and follows the standards provided by Bureau of Indian Standards (BIS), Indian Council of Medical Research (ICMR), CPCB and World Health Organization (WHO). The slight difference in pH value was due to the low annual disparity in free $\mathrm{CO}_{2}$ in the sampling regions for the two years of study. Singh et al. (2016), Siddiqui and Pandey (2019) and Pandey et al. (2015) reported studies of physico-chemical parameters of the Ganga river and observed that the range of pH was 7.1-7.8, 7.6-7.8 and 8.2-8.45, respectively at different sites of Varanasi which is in accordance with the present study. However, Pandey et al. (2014) shown that the Prayagraj region's pH range was 8.1-8.4. Similar results were reported by Dixit et al. (2017), Kumar et al. (2020b) and Satya and Narayan (2018) for pH values that ranged from 7.4-8.1, 7.6-8.8 and 6.0-8.0 in river Ganga at nearby cities Kanpur and Patna.

The dissolved solids including chloride, calcium and magnesium salts in the water samples were responsible for the conductivity level. According to BIS, CPCB, ICMR and WHO, the maximum allowable conductivity level is $300 \mathrm{mho} / \mathrm{cm}$ in the water. The measured conductivity values for water samples at sampling sites in the river Ganga varies between $191-386 \mathrm{mho} / \mathrm{cm}$ (Table 2). The average conductivity was more (336.2 and $342.4 \mathrm{mho} / \mathrm{cm}$ ) in June 2017 and slightly lowers (273 and $274 \mathrm{mho} / \mathrm{cm}$ ) in March 2018 than the permissible limit in both the cities. This change may be due to the seasonal change or Ganga clean drive by government initiatives. Although there is no direct impact of water conductivity on human health but its estimation is required to evaluate the mineralization rate of present mineral salts and determination of the number of chemical reagents implied to treat the water (Kavcar et al. 2009). Higher conductivity leads to the lowering of drinking water's aesthetic value, eliminating habitat-forming plant and corrosion of the metal surface of industrial equipments such as boiler (Rahmanian et al. 2015).

The maximum threshold limit of total suspended solids (TSS) in drinking water and the freshwater stream is not mentioned by any water regulatory bodies (Kumar and Puri, 2012). However, norms used in the guideline are stated and based on indirect effects on human health due to particulate matter. Water regulatory authority of some countries such as National Water Quality Standard (NWQS) Malaysia, provided the maximum threshold limit of TSS 150 mg/L for rivers which support aquatic life (Al-Badaii et al. 2013). The TSS values in water samples of river Ganga at study sites were observed in the range of $62-$ $167 \mathrm{mg} / \mathrm{L}$ (Table 2). The average TSS value for June 2017 was observed $107.1 \mathrm{mg} / \mathrm{L}$, whereas the average TSS value during March 2018 was found 113.6 $\mathrm{mg} / \mathrm{L}$. This change in the TSS value is not substantial in two different years of study. Pandey et al. (2015) reported the TSS value range $60-117 \mathrm{mg} / \mathrm{L}$ in the Ganga water samples at different sites of Varanasi Ghats during 2012 and 2013.

The total dissolved solids (TDS) values in the Prayagraj region at different sites range from 209 to $343 \mathrm{mg} / \mathrm{L}$. The highest value obtained was $343 \mathrm{mg} / \mathrm{L}$ recorded at site S3 (Mehdhori Gaon Khachar) during June 2017, and the lowest value obtained was $209 \mathrm{mg} / \mathrm{L}$ at site S2 (Daraganj ghat) during March 2018 (Table 2). Additionally, the TDS concentrations in the sampling sites of Varanasi ranged from 227 to $321 \mathrm{mg} / \mathrm{L}$ during two years of study. The lowest concentration was $227 \mathrm{mg} / \mathrm{L}$ recorded at site S10 (Sheetala Ghat) and the highest concentration was $321 \mathrm{mg} / \mathrm{L}$ at site 8 . In the present study, the TDS concentration observed was less than reported for the Prayagraj and Varanasi areas in the range of $284-707 \mathrm{mg} / \mathrm{L}$ and $454-703 \mathrm{mg} / \mathrm{L}$ respectively (CPCB 2013). It was noticed that upstream and downstream sites of both cities have TDS values with no significant difference because anthropogenic and land use activities were expanded more in both ends. Moreover, TDS values are within the permissible level (500 mg/L) set by BIS, CPCB and WHO (Kumar and Puri 2012). Pandey et al. (2015) also reported the concentration range of TDS in river Ganga at Varanasi and Prayagraj, the values obtained were $266-344$ mg/L and $185-271 \mathrm{mg} / \mathrm{L}$, respectively.

The hardness of water is not a pollution indicator but signifies water quality primarily caused by the presence of $\mathrm{Ca}^{2+} \mathrm{and} \mathrm{Mg}^{2+}, \mathrm{HCO}_{3}{ }^{-}, \mathrm{SO}_{4}{ }^{2-}, \mathrm{Cl}^{-}$, and $\mathrm{NO}_{3}{ }^{-}$ in water. The hardness of water has no known adverse influences on health (WHO 2011). However, some evidence has pointed out its impact on human health, mainly stone formation in kidney and heart diseases, if the water with hardness of $150-300 \mathrm{mg} / \mathrm{L}$ or above can be consumed at a rate of 2 liters per day (Mitra et al. 2018). Water has been classified as soft, moderate, hard and very hard based on hardness value $>60,60-120,120-180$ and $<180 \mathrm{mg} / \mathrm{L}$ of $\mathrm{CaCO}_{3}$, respectively (McGowan 2000). The average value of water hardness recorded was $275.2 \mathrm{mg} / \mathrm{L}$ and $246.4 \mathrm{mg} / \mathrm{L}$ in June 2017 for Prayagraj and Varanasi sampling sites respectively. The hardness values of water samples during March 2018 were more or less similar (287.0 and $244.2 \mathrm{mg} / \mathrm{L}$ ). Thus, the negligible variation was observed in the water hardness for two years (i.e. June, 2017 and March, 2018) at study sites. The water hardness at study regions observed was within the range of permissible limit (300 mg/L) recommended by BIS. These finding was in agreement with Kumar et al. (2020b), who mentioned similar pattern of the hardness of Ganga water at the middle Ganga plains in different seasons. Alkalinity in water is due to the presence of carbonates, bicarbonates and hydroxides. Alkalinity recorded the highest average value of $161.6 \mathrm{mg} / \mathrm{L}$ during the June 2017 . The range of alkalinity was observed between 114 to $197 \mathrm{mg} / \mathrm{L}$ during two years of study at different sites (Table 2). The average value of alkalinity was $160.2 \mathrm{mg} / \mathrm{L}$ in June 2017 and $125.2 \mathrm{mg} / \mathrm{L}$ in March 2018 at Prayagraj regions. The average level of alkalinity was observed $161.2 \mathrm{mg} / \mathrm{L}$ in June 2017 and $155.8 \mathrm{mg} / \mathrm{L}$ in March 2018 at Varanasi regions. The value of alkalinity in the study site was found at the upper side of the permissible limit (120 mg/L) as per BIS records. Pandey et al. (2015) also demonstrated a higher range of total alkalinity (230-279 mg/L) in river Ganga at Varanasi.

Increased nutrients (nitrates and phosphates) are among the primary reasons for low water quality in the freshwater stream (Davie 2003). Agriculture and urban runoff include fertilizer, domestic, sewage and industrial wastewater discharges are major routes of entry into water bodies in terms of nutrient pollution (Dubey et al. 2012). Nitrate and phosphate concentrations in freshwater can cause oxygen depletion that resultant in the deterioration of aquatic life. Consumption of high concentrations of nitrate and phosphate contaminated water causes the blue baby syndrome, muscle damage, breathing problems, and kidney failure (Davie 2003). The maximum permissible limit of $\mathrm{NO}_{3}{ }^{-}-\mathrm{N}$ level is in the range of $20-45 \mathrm{mg} / \mathrm{L}$ set by BIS, ICMR and WHO (Table 2). In the present study, the $\mathrm{NO}_{3}{ }^{-}-\mathrm{N}$ concentration observed was ranged between 2.52 to $4.92 \mathrm{mg} / \mathrm{L}$. The decrease in overall level in the $\mathrm{NO}_{3}{ }^{-}-\mathrm{N}_{\text {due }}$ to temporal effect was observed $~ 28 \%$ in Ganga water. The concentration of nitrates observed in Ganga water was below the level as prescribed by water regulatory authorities. In this study of two years, $\mathrm{PO}_{4}{ }^{-}-\mathrm{P}$ concentration was observed in the range of $0.92-1.82 \mathrm{mg} / \mathrm{L}$ at Prayagraj and Varanasi's sampling sites. The average 
concentration of phosphate content was $1.46 \mathrm{mg} / \mathrm{L}$ and $1.15 \mathrm{mg} / \mathrm{L}$ during June 2017 and March 2018, respectively. The trend of phosphate concentration in the particular region was more or less similar and not much effect of time was observed.

Chloride is present naturally in all water types; however, its major contribution is the runoff of inorganic fertilizers from agricultural land and sewage discharge (Lkr et al. 2020). The chloride concentration variation was $65 \mathrm{mg} / \mathrm{L}$ (at site 2 and 7) to $104 \mathrm{mg} / \mathrm{L}$ (at site 7) in two different times for two years (June 2017 and March 2018). The variation was recorded ranging between 65 to $104 \mathrm{mg} / \mathrm{L}$ and 65 to $92 \mathrm{mg} / \mathrm{L}$ during June 2017 and March 2018 , respectively. In comparison, Singh (2010) and Pandey et al. (2015) were recorded the spatial-temporal variation of chloride concentration in Ganga water in the range of 8.2$81.5 \mathrm{mg} / \mathrm{L}$ and $21.4-94.7 \mathrm{mg} / \mathrm{L}$ at the Varanasi region. Pandey et al. (2014) reported the variation of chloride concentration in water samples at Prayagraj, ranging between 8.2 to $21.4 \mathrm{mg} / \mathrm{L}$. According to Hem (1985), the major sources of sulfate in the freshwater stream are rocks weathering and human activities such as mining, water discharge and fossil fuel combustion. The sulfate values varied from 32.3 (site S2) to $49.0 \mathrm{mg} / \mathrm{L}$ (site S3) at Prayagraj and 35.0 (site $\mathrm{S} 10$ ) to $52.0 \mathrm{mg} / \mathrm{L}$ (site S6) at Varanasi during sampling periods. A similar range of results (37.9-54.2 mg/L and 16-36 mg/L) were also obtained in Ganga water samples at Varanasi by Pandey et al. (2015) and Singh et al. (2016), correspondingly. The chloride and sulfate concentration in the Ganga water samples observed were within the permissible limit suggested by BIS, ICMR and CPCB. The iron content in the sampling sites ranges from 0.13 to $0.218 \mathrm{mg} / \mathrm{L}$. Iron content was recorded highest at site S9 (Samane Ghat, Varanasi) during two years of study. The iron level in studied samples fell within the acceptable limit (0.3-1.0 mg/L) of BIS, ICMR and CPCB, except the WHO's water specification $(0.1 \mathrm{mg} / \mathrm{L})$.

Chemical oxygen demand (COD), biochemical oxygen demand (BOD) and dissolved oxygen (DO) are important parameters for water quality evaluation. They reflect the physical and biological processes prevailing in the water that indicates the degree of pollution in water bodies. During the study, the spatialtemporal variations in COD, BOD and DO recorded were 30.7-54.3, 3.2-4.9 and 6.7-8.2 mg/L at the ten selected sites. The slight difference (0.3 mg/L) in average DO concentration may be mainly due to the water temperature difference of about $4^{\circ} \mathrm{C}$. The dissolved oxygen's desirable limit is more than $4 \mathrm{mg} / \mathrm{L}$ as per BIS and CPCB standards. Pandey et al. (2015) observed that the COD, BOD and DO values range between 53.5-79.6, 37.4-58.7 and 3.7-5.8 mg/L, respectively, in the Ganga river of Varanasi region. CPCB (2013) also recorded the range of COD, BOD and DO concentration 46.2-156.2, 3.7-9.6 and 7.0-7.8 $\mathrm{mg} / \mathrm{L}$ correspondingly at Varanasi region and 17.3-192, 2.6-5.6 and 6.0-9.8 mg/L respectively at Prayagraj region. The DO level recorded at all the sites is sufficient for the planktons to survive and perform various physiological water activities (Al-Badaii et al. 2013).

\section{Biological Parameters Analysis}

Transparency is a measure of the water's clarity and is essential for the survival of aquatic plants that require sunlight for photosynthesis. Transparency depth values can be influenced significantly by numerous factors such as day time at which measurement has recorded clearness of the sky (cloudy, partly cloudy or sunny) and suspended solids in water, including plankton (Verma and Saksena 2010; Sarkar et al. 2019). The value of transparency depth recorded was from 0.35-0.62 $\mathrm{m}$ for two years in the present study. Changes in values at the study sites are possibly due to the differences in bottom sediments and temperature, dissolved organic matter or entry of municipal and industrial waste material. The higher value of transparency depth noted was during March 2018 ( $0.51 \mathrm{~m}$ ) than June 2017 (0.43 m). A similar kind of variation in transparency depth was demonstrated by Matta et al. (2017).

During this study, the spatial-temporal variation in algal cell concentration and algal cell density observed were in the range of $3.1 \times 10^{3}-10.7 \times 10^{3}$ cells $/ \mathrm{mL}$ and $12.5-28.4 \mathrm{mg} / \mathrm{L}$ respectively. The chlorophyll-a (Chl-a) concentration range was found $0.84 \times 10^{-2}-2.21 \times 10^{-2} \mathrm{mg} / \mathrm{L}$. The variation in three biological parameters (Chl-a, algal cell concentration and algal cell density) are closely related (Table 2). Eutrophication and global warming are the main reasons to promote the excessive growth of algae globally in freshwater bodies (Davis et al. 2009; Sarkar et al. 2019). The toxic cyanobacterial occurrence causes many problems for instance, bad odour, low esthetic value, water quality deterioration and oxygen depletion in water which can impair tourism, transportation and ecosystem health (Son et al. 2015).

The increase in nutrient load in water bodies leads to high productivity that modifies the structure of water communities. Productivity measurement, algal and bacterial concentrations are important environmental change indicators that include acidification, climatic change and eutrophication (Dam et al. 1994). However, these biological parameters varied by numerous factors such as nutrients, temperature and organic matters. The gross productivity (GP) and net primary productivity (NPP) at different Prayagraj and Varanasi sites recorded were between $18.5-30.8 \mathrm{mg} \mathrm{C} / \mathrm{m}^{2} / \mathrm{h}$ and $9.5-16.9 \mathrm{mg} \mathrm{C} / \mathrm{m}^{2} / \mathrm{h} \mathrm{for} \mathrm{two} \mathrm{years} \mathrm{of}$ study when the average sunlight per day was $10 \mathrm{~h}$. The increase in NPP to GP value approximately $6.5-11.9 \%$ was found in March 2018 , which could be due to higher water transparency in March 2018. Limited studies are available concerning the assessment of productivity and biological indicators and their effect on Ganga water quality (Siddiqui and Pandey 2019; Pandey and Yadav 2015). Pandey and Yadav (2015) reported that the GP at different sites in the Ganga river of Varanasi region ranged from $\sim 2-8.5 \mathrm{mg} \mathrm{C} / \mathrm{m}^{2} / \mathrm{h}$, which are in agreement with our results. Productivity variables such as GP, Chl-a and algal biomass showed synchrony with the concentration of nutrients and indicates that the river Ganga polluted at Varanasi and Prayagraj regions.

Fecal coliform and total coliform concentration in both regions observed were higher than the criteria at most locations, while the highest value always observed were at Varanasi (site-S9, Samne ghat; 11300 MPN/100 mL). CPCB (2013) reported fecal coliform and total coliform level 8000-46000 and 13000$70000 \mathrm{MPN} / 100 \mathrm{~mL}$ respectively in the six-year Ganga survey (2006-2011) for the Varanasi region. These biological parameters observed were also in the range of $3000-5000$ and $7000-14000 \mathrm{MPN} / 100 \mathrm{~mL}$ respectively in the Prayagraj region.

\section{Spatial-temporal And Water Quality Index (Wqi) Analysis}

The descriptive statistics for spatial-temporal variation of water quality parameters at ten sampling sites of Prayagraj and Varanasi city studied for two years are presented by the box-whisker plot in Fig. 3 (a) and (b). Box and whisker plots represent the full spatio-temporal dynamics of two-year studied physical, nutrient, chemical, ionic and biological parameters investigated for the river Ganga water samples. For most parameters, the higher standard deviation indicates temporal and spatial variations likely caused by polluting sources and/or climatic factors. 
The WQI approach applied to assess river Ganga's water quality intending to provide a valid and straightforward method for expressing several parameters rapidly and conveniently. Eight parameters employed by WQI can indicate the water quality at various sampling points of Prayagraj and Varanasi regions. The average WQI score obtained was 46.31 and 50.66 for two different times, June 2017 and March 2018, respectively (Table 3). It was apparent that the water samples of study sites were falls under medium and bad category for drinking or bathing. WQI value observed was mainly due to the high concentration of fecal coliform in the water samples. Based on WQI, water qualities identified at sampling points in the river may indicate that it can be suitable for transportation, irrigation and water supply purposes. Comprehensively, comparable research was conducted in many countries such as surface water of Amazonia Rivers, Brazil (Medeiros et al. 2017), Sarayduzu Dam Lake, Turkey (Kükrer and Mutlu 2019), Kafr El-Sheikh Governorate, Egypt (Jahin et al. 2020) and the Cau river, Vietnam (Son et al. 2020). WQI analysis showed that Ganga water in the sampling regions approaches medium/bad quality conditions but increased human activity warns us about future consequences. Various WQI studies has been recently performed in the various stretches of river Ganga (Kumar et al. 2021; Dimri et al. 2020; Kumar et al. 2020b).

Table 3

Water Quality Index at 10 sampling sites of the river Ganga at Prayagraj and Varanasi using NSFWQI method.

\begin{tabular}{|c|c|c|c|c|c|c|c|c|c|c|c|}
\hline \multirow[t]{2}{*}{ Duration } & \multicolumn{5}{|c|}{ Prayagraj } & \multicolumn{5}{|c|}{ Varanasi } & \multirow[t]{2}{*}{ Over all } \\
\hline & s1 & S2 & S3 & S4 & S5 & S6 & s7 & S8 & s9 & S10 & \\
\hline June 2017 & 49.46 & 46.89 & 45.61 & 46.74 & 47.01 & 43.87 & 45.25 & 48 & 45.8 & 44.49 & 46.31 \\
\hline March 2018 & 51.52 & 49.99 & 50.68 & 49.66 & 51.31 & 50.79 & 49.21 & 52.22 & 50.52 & 50.67 & 50.66 \\
\hline
\end{tabular}

Morphological Evaluation Of Cyanobacteria Of River Ganga

Morphological observation of phytoplanktonic water samples by microscopy revealed the diversity of cyanobacterial genera in river Ganga at study sites (Supplementary Fig. 1). It was observed that colonial and buoyant cyanobacteria were abundant preferably the genus Microcystis. Diverse cyanobacterial colonies showed variations in individual cell sizes, cell arrangement, colony morphology and mucilage characteristics. Besides Microcystis, many other species belonging to the genera Leptolyngbya, Planktothrix, Anabaena, Gleocapsa, Phormidium, Hormogonia, Oscillatoria, Aphanizomenon, Aphanocapsa, Scynecoccocus were also observed (Supplementary Fig. 1). Similarly, Rishi and Awasthi (2015) recorded the most dominating genera in river Ganga at Kanpur, U.P, India were Anabaena, Microcystis, Cylindrospermum, Phormidium Aphanizomenon, Chroococcus, Lyngbya, Nostoc, Nodularia, Spirulina and Oscillatoria. Other studies have also demonstrated the widespread occurrence of Oscillatoria, Leptolyngbya, Scynecoccocus, Anabaena in river Ganga (Shukla et al. 2015; Dixit et al. 2017; Sarkar et al. 2019). According to taxonomic keys, the cyanobacteria species were determined based on cell structure, colony morphology and mucilage characteristics. Since the toxic and non-toxic cyanobacterial species can co-exist in an environment and are indistinguishable by microscopy technique (Romanis et al. 2021), therefore, MCs producers were characterized based on the molecular approach (Casero et al. 2019) and MCs detection (Kumar et al. 2020b).

\section{Molecular characterization of uncultured cyanobacteria in water samples of river Ganga}

The mcy genes (mcyA to mcyJ) that regulate MCs synthesis in potentially toxic cyanobacteria have been identified and sequenced (Dittmann and Borner 2005). MCs standard structure is cyclo (D-Ala-L-X-D-MeAsp-L-Y-Adda-D-Glu-Mdha), where $X$ and $Y$ are variable L-amino acids. Figure 2 shows the structure of MC-LR, where $X$ is L-leucine and $Y$ is L-arginine. In this study, PCR was conducted with general and genus-specific primers for three genes ( $m c y A$, mcyB and mcyE) designed (Fig. 2) to amplify the generic mcyE (812 bp), Microcystis mcyE (247 bp), Anabaena mcyE (244 bp), Planktothrix mcyE (249 bp), mcyA (291 bp) and mcyB (973 bp) genes from phytoplanktonic uncultured water samples of river Ganga from each of the 10 sampling sites of Varanasi and Prayagraj regions. The PCR amplification with primers for the Anabaena and Planktothrix mcyE failed to produce any amplicons (data not shown). The result indicates that Anabaena and Planktothrix cells if present in the collected phytoplanktonic water samples were non-toxic due to absence of mcy genes. However, the desired length of PCR products was amplified using the oligonucleotide primers sets for generic mcyE, Microcystis mcyE, mcyA and mcyB genes from all the genomic DNA of the uncultured cyanobacteria extracted individually from water samples of 10 different sites as shown in Fig. 4. These findings of PCR amplification were same for both the years of study. Previous studies have also shown the identification and detection of toxic cyanobacteria in environmental samples based on mcy genes using a PCR technique (Baker et al. 2002, Ribeiro et al. 2020) with universal primers targeting conserved sequences (Hisbergues et al. 2003) and species-specific primers designed based on differences within the mcy gene clusters (Rantala et al. 2006), respectively. The mcy genes preferably targeted are mcyA, B, C, D and E however, in several studies a combination of the mcy genes were used (Ouellette et al. 2006). The mcyA gene, because of its conserved sequences, is an appropriate target for PCR based identification of toxic cyanobacteria (Hisbergues et al. 2003; Rantala et al. 2004). The mcyB gene regulates the activation of amino acids as aminoacyl adenylate and it was followed by peptide bond formation by the condensation domain in growing MC molecule (Tillett et al. 2000). The glutamate-activating adenylation domain is encoded by mcyE gene and all known $\mathrm{MC}$ variants possess D-glutamate and the carboxyl group of the glutamate side-chain is crucial for the toxicity. Therefore, the mcyE gene used for detection of MCs-producing cyanobacteria (Goldberg et al. 1995). The amplicons of generic mcyE, mcyA and mcyB genes from uncultured cells of Ganga water samples were sequenced and submitted in the NCBI database. Gene bank accession ID numbers are MZ222414, MZ222415 and MZ222414 for mcyE, mcyA and mcyB genes, respectively. The partial gene sequence similarities for mcyA and mcyE genes from uncultured cells of water samples with the genus Microcystis were more than $95 \%$. The neighbor-joining tree developed using mcyA and mcyE gene sequences showed the grouping with cyanobacterial genus Microcystis (Fig. 4). These results are consistent with the microscopic analysis and advocate the presence of genus Microcystis in river Ganga. However, based on sequenced mcyB amplicons from uncultured cells, the phylogenetic assessment suggested close proximity with filamentous cyanobacterial genus Oscillatoria 
and Planktothrix. Thus, PCR amplification and phylogenetic analysis propose the presence of various genera of cyanobacteria possessing putative mcy genes in river Ganga.

\section{Quantification of MC-LR equivalence in Ganga water by PPIA and HPLC method}

Increasing pollution in river Ganga due to anthropogenic activities triggers MCs producers and MCs concentration in the water (Dixit et al. 2017). A study indicates that MCs that produced intracellularly have released into the extracelluar environments during cell lysis due to stress or age (Wei et al. 2020). MC-LR is one of the most common and toxic MCs (Zhang et al. 2021). In this work, the MC-LR equivalence concentration in phytoplanktonic water samples collected from 10 different sampling points of Varanasi and Prayagraj regions was detected by PPIA and HPLC methods. The colorimetric PPIA technique determined the MC-LR equivalence concentration in river Ganga at study sites attaining low detection (LOD) even below $1 \mu \mathrm{g} / \mathrm{L}$ (Supplementary Fig. 2). PPIA method ensures the presence of MC-LR equivalence in all the collected Ganga water samples (Fig. 5). The HPLC method's calibration curve for MC-LR was built considering the areas of the chromatographic peaks calculated at its six different concentration levels, ranging from $0.1-500 \mu \mathrm{g} / \mathrm{L}$. The good linearity was obtained for the regression equation of the calibration curve of HPLC analysis and it was $Y=196.12 X\left(R^{2}=0.98\right)$, where $Y$ is the area of MC-LR peak and $X$ is the concentration of the MC-LR in $\mu \mathrm{g} / \mathrm{L}$. The limit of detection $(\mathrm{S} / \mathrm{N}=3)$ and limit of quantification $(\mathrm{S} / \mathrm{N}=5)$ was $0.5 \mu \mathrm{g} / \mathrm{L}$ and $1.1 \mu \mathrm{g} / \mathrm{L}$, respectively. The range of MC-LR equivalence concentration was observed to be $23-172 \mathrm{ng} / \mathrm{L}$ by PPIA, whereas, MC-LR equivalence concentration range was obtained to be $13-97$ $\mathrm{ng} / \mathrm{L}$ using HPLC at various sites of Varanasi and Prayagraj. The results of the actual MC-LR equivalence concentration obtained in water samples by the two mentioned methods are summarized in Fig. 5. The MC-LR equivalence concentrations observed by PPIA slightly differ from the HPLC values; however, still being of the same order of magnitude (Fig. 5). This difference may be possible due to the presence of compounds in river Ganga water that interferes on the PPIA, despite the high dilutions used (Garibo et al. 2014; Chen et al. 2005). These analyses further confirm the occurrence of putative MCs producing cyanobacterial strains in the Ganga water at Prayagraj and Varanasi regions. The concentration of MC-LR equivalence ( $\geq 60 \mathrm{ng} / \mathrm{L})$ was high at Rasoolabad Ghat (S4), Daraganj Ghat (S2) and Mehdori Village (S3) in Prayagraj, where human activities are prevalent. In Varanasi, MC-LR equivalence was higher at Dashashwamegh Ghat (S6) and Ravidash Mandir Ghat (S8). However, between two cities, MC-LR equivalence concentrations were generally higher in Prayagraj. The differences observed may reflect the influence of environmental factors on MCs production. The study demonstrated that MCs production is sensitive to several physico-chemical parameters, including light intensity, temperature, rainfall, $\mathrm{pH}$, iron concentration, nitrogen and phosphorus concentrations (Kaebernick and Neilan 2001, Wagner et al. 2019). This is the first study that reported the quantitative MC-LR equivalence estimation in the water of river Ganga. However, MC-LR equivalence concentration is far less in river Ganga's water than the harmful exposure concentration ( $1 \mu \mathrm{g} / \mathrm{L})$ recommended by WHO (WHO, 2011). PPIA is more convenient to perform and could be used as a primary method to detect MCs presence and its concentration in the water reservoirs (Massey et al. 2020).

\section{Isolation and characterization of MC producing cyanobacteria from river Ganga}

Three different cyanobacterial strains were isolated and purified by plating and liquid culture methods in BG-11 media. Visualization using phase contrast microscope showed that one of the isolates is the macroscopic, circular, colonial and gas vacuolated form (Ganga isolate 1), the second one is of noncolonial, filamentous structure (Ganga isolate 2) and the third one is the polymorphic colonial form (Ganga isolate 3) (Supplementary Fig. 3). Of the three isolates, only Ganga isolate 1 amplifies the PCR products for mcy genes (Fig. 6). Initially, based on morphological identification, the Ganga isolate 1 was identified as Microcystis. Furthermore, the partial 16S rDNA fragment from Ganga isolate 1 was amplified using cyanobacterial specific universal primer. The amplicon was sequenced and submitted in the NCBI database. Gene bank accession ID number is MZ027619. The BLAST hit of partial 16S rDNA gene sequence of Ganga isolate 1 indicates its maximum phylogenetic identity with Microcystis aeruginosa LMECYA 1 (Fig. 6). Results confirmed that the isolate was Microcystis. Thus the result of morphological identification is supported by phylogenetic analysis based on partial 16S rDNA sequence as shown in Fig. 6. Only one of the three isolated cultures, i.e. Ganga isolate 1 (Microcystis) from river Ganga was a MCs producer based on PPIA and HPLC method (Fig. 6). The majority of the MCs positive water bodies were eutrophic and turbid. The researcher also revealed that physico-chemical factors directly or indirectly affect cell growth and MCs generation in water bodies (Bouaïcha et al. 2019). In this study not much correlation has been drawn between the physico-chemical parameters and MC-LR equivalence concentration at the sampling sites, therefore, it is impossible to reliably determine the cause for putative MCs producers in river Ganga. Though, a weak positive influence of phosphate, ammonium and temperature has been observed. In the future, extensive research with more sampling and a more extended monitoring period is needed to elucidate the relative importance and correlation.

\section{Conclusion}

The polyphasic approach was applied to ascertain the water quality at recreational sites of the river Ganga flowing in the stretch from Prayagraj to Varanasi by assessing physico-chemical, WQI analysis combined with toxicological characters such as MCs producers based on the generic and species-specific primers (mcyE, A and B) and MC-LR equivalence level detection. Physico-chemical and WQI analysis indicates that the water quality at recreational sites is in an alarming situation. This study provides the first evidence about the prevalence of putative MCs producing cyanobacteria with MC-LR equivalence concentration below the permissible limit of WHO. The amount and variability of MC-LR equivalence concentrations may be related to variability in nutrient enrichment at different sites. Ganga isolate (named as Ganga isolate 1) was identified to be Microcystis, possessing mcy genes with MCs production potential. Higher alkalinity, turbidity and temperature may favor the growth of MCs producing cyanobacteria in river Ganga. Human populations and domestic animals living in this region may appear to be exposed to MCs through contaminated dietary components and/or drinking water. Hence, it is essential to perform the periodic assessment of MC producers and their toxins to reduce the chances of water-borne diseases, ensure good health for maintenance and restoration of the river Ganga water sanctity.

\section{Declarations}


This submitted work has not been published previously (except in the form of a project reports), and is not under consideration for publication elsewhere, it's publication is approved by all authors and tacitly or explicitly by the responsible authorities where the work was carried out, and if accepted, it will not be published elsewhere in the same form, in English or in any other language, including electronically without the written consent of the copyright holder.

\section{Ethics approval and consent to participate}

NA

\section{Availability of data and materials}

NA

\section{Declaration of Competing Interests}

The authors declare that they have no competing interests.

\section{Acknowledgements}

VK acknowledges the National Academy of Science India (NASI) for Ganga Research Associate fellowship from NASI, Allahabad. The authors gratefully acknowledge the lab facilities, advices and suggestions given by Distinguished Prof. L. C. Rai. We also thank Dr. Ruchi Rai for critical reading of the manuscript.

\section{Author Contributions}

VK conceived and designed the experiments, performed the microscopic study and overall analysis of the data. VK and SK performed the sampling, physicochemical analysis, phylogenetic tree analyses and interpreted the results. SK and IY performed the PPIA and HPLC experiments. VK, AC and SR performed the PCR experiments. VK and SP performed the cyanobacteria isolation and its maintenance. VK and SK wrote the paper.

\section{Funding}

The study was supported by the National Academy of Science India (NASI) (Project code: M21-165 awarded to VK).

\section{References}

1. Al-Badaii F, Shuhaimi-Othman M, Barzani Gasim M (2013) Water Quality Assessment of the Semenyih River, Selangor, Malaysia. J Chem 2013(871056):110. http://dx.doi.org/10.1155/2013/871056

2. APHA (1998) Standard Methods for the Examination of Water and Waste Water. 19th ed. American Public Health Association, Washington.

3. Baker JA, Entsch B, Neilan BA, McKay DB (2002) Monitoring changing toxigenicity of a cyanobacterial bloom by molecular methods. Appl Environ Microbiol 68(12):6070-6076. doi:10.1128/aem.68.12.6070-6076.2002

4. Behera BK, Chakraborty HJ, Patra B, Rout AK, Dehury B, Das BK, Sarkar DJ, Parida PK, Raman RK, Rao AR, Rai A. Mohapatra T (2020) Metagenomic Analysis Reveals Bacterial and Fungal Diversity and Their Bioremediation Potential From Sediments of River Ganga and Yamuna in India. Front Microbiol 11:556136. doi:10.3389/fmicb.2020.556136

5. Benton AH, Werner WE (1972) Manual of field biology and Ecology. $5^{\text {th }}$ ed. Burgess publishing company, Minneapolis, Minnesota.

6. Bouaïcha N, Miles CO, Beach DG, Labidi Z, Djabri A, Benayache NY, Nguyen-Quang T (2019) Structural Diversity, Characterization and Toxicology of Microcystins. Toxins 11(12):714. doi:10.3390/toxins11120714

7. Casero MC, Velázquez D, Medina-Cobo M, Quesada A, Cirés S (2019) Unmasking the identity of toxigenic cyanobacteria driving a multi-toxin bloom by high-throughput sequencing of cyanotoxins genes and 16S rRNA metabarcoding. Sci Total Environ 665:367-378. https://doi.org/10.1016/j.scitotenv.2019.02.083

8. Chen J, Xie P, Li L, Xu J (2009) First identification of the hepatotoxic microcystins in the serum of a chronically exposed human population together with indication of hepatocellular damage. Toxicol Sci 108(1):81-89. https://doi.org/10.1093/toxsci/kfp009

9. Chen YM, Huang R, Chou HN (2005) Application of Protein Phosphatase 1 Inhibition Assay and Reversed Phase Liquid Chromatography for the Detection of Microcystins in Algal Dietary Supplements. J Food Drug Anal 13(1):71-77. https://doi.org/10.38212/2224-6614.2545

10. Codd GA, Morrison LF, Metcalf JS (2005) Cyanobacterial toxins: risk management for health protection. Toxicol App Pharmacol 203(3):264-272. https://doi.org/10.1016/j.taap.2004.02.016

11. CPCB (2013) A Report on pollution assessment: RIVER GANGA. (https://cpcb.nic.in/wqm/pollution-assessment-ganga-2013.pdf)

12. Dam VH, Mertens A, Sinkeldam J (1994) A coded checklist and ecological indicator values of freshwater diatoms from the Netherlands. Neth J Aquat Ecol 28:117-133. https://doi.org/10.1007/BF02334251

13. Davie T (2003) Fundamental of Hydrology. Routledge, Taylor \& Francis Group, London, New York.

14. Davis TW, Berry DL, Boyer GL, Gobler CJ (2009) The effects of temperature and nutrients on the growth and dynamics of toxic and non-toxic strains of Microcystis during cyanobacteria blooms. Harmful Algae 8(5):715-725. https://doi.org/10.1016/j.hal.2009.02.004 
15. Dimri D, Daverey A, Kumar A, Sharma A (2020) Monitoring water quality of River Ganga using multivariate techniques and WQI in upper Ganga basin of Uttarakhand, India. Environ Nanotechnol Monit Manag 15:100375. https://doi.org/10.1016/j.enmm.2020.100375

16. Dittmann E, Borner T (2005) Genetic contributions to the risk assessment of microcystin in the environment. Toxicol Appl Pharmacol 203(3):192-200. doi:10.1016/j.taap.2004.06.008

17. Dixit RB, Patel AK, Toppo K, Nayaka S (2017) Emergence of toxic cyanobacteria species in the Ganga River, India, due to excessive nutrient loading. Ecol Indic 72:420-427. https://doi.org/10.1016/j.ecolind.2016.08.038

18. Dubey VK, Sarkar UK, Kumar RS, Mir JI, Pandey A, Lakra WS (2012) Length-weight relationships (LWRs) of 12 Indian freshwater fish species from an unimpacted tropical river of Central India (River Ken). J Appl Ichthyol 28:854-856. https://doi.org/10.1111/j.1439-0426.2012.02005.x

19. Dutta V, Dubey D, Kumar S (2020) Cleaning the River Ganga: Impact of lockdown on water quality and future implications on river rejuvenation strategies. Sci Total Environ 743(4): 140756. https://doi.org/10.1016/j.scitotenv.2020.140756

20. Fastner J, Flieger I, Neumann U (1998) Optimised Extraction of Microcystins from Field Samples - A Comparison of Different Solvents and procedures. Water Res 32(10):3177-3181. https://doi.org/10.1016/S0043-1354(98)00073-6

21. Garibo D, Flores C, Cetó X, et al. (2014) Inhibition equivalency factors for microcystin variants in recombinant and wild-type protein phosphatase 1 and $2 A$ assays. Environ Sci Pollut Res Int 21(18):10652-10660. doi:10.1007/s11356-014-3065-7

22. Genuário DB, Silva-Stenico ME, Welker M, Beraldo Moraes LA, Fiore MF (2010) Characterization of a microcystin and detection of microcystin synthetase genes from a Brazilian isolate of Nostoc. Toxicon 55:846-854. https://doi.org/10.1016/j.toxicon.2009.12.001

23. Gobler CJ, Davis TW, Coyne KJ, Boyer GL (2007) Interactive influences of nutrient loading, zooplankton grazing and microcystin synthetase gene expression on cyanobacterial bloom dynamics in a eutrophic New York lake. Harmful Algae 6(1):119-133. https://doi.org/10.1016/j.hal.2006.08.003

24. Goldberg J, Huang H, Kwon Y, Greengard P, Nairn AC, Kuriyan J (1995) Three-dimensional structure of the catalytic subunit of protein serine/threonine phosphatase-1. Nature 376: 745-753. DOI: 10.1038/376745a0

25. Hem JD (1985) Study and interpolation of the chemical characteristics of natural water. US Geological Survey Water Supply Paper 2254:1-263. https://doi.org/10.3133/wsp1473_ed1

26. Hisbergues M, Christiansen G, Rouhiainen L, Sivonen K, Borner T (2003) PCR-based identification of microcystin-producing genotypes of different cyanobacterial genera. Arch Microbiol 180:402-410. DOI: 10.1007/s00203-003-0605-9

27. Jahin HS, Abuzaid AS, Abdellatif AD (2020) Using multivariate analysis to develop irrigation water quality index for surface water in Kafr El-Sheikh Governorate, Egypt. Environ Technol Innov 17:100532. https://doi.org/10.1016/j.eti.2019.100532

28. Jungblut AD, Hawes I, Mountfort D, Hitzfeld B, Dietrich DR, Burns BP et al. (2005) Diversity within cyanobacterial mat communities in variable salinity meltwater ponds of McMurdo Ice Shelf, Antarctica. Environ Microbiol 7:519-529. doi: 10.1111/j.1462-2920.2005.00717.x

29. Kaebernick M, Neilan BA (2001) Ecological and molecular investigations of cyanotoxin production. FEMS Microbiol Ecol 35(1):19. https://doi.org/10.1111/j.1574-6941.2001.tb00782.x

30. Kamboj N, Kamboj V (2019) Water quality assessment using overall index of pollution in riverbed-mining area of Ganga-River Haridwar, India. Water Sci 33(1):65-74. doi: 10.1080/11104929.2019.1626631

31. Kavcar P, Sofuoglu A, Sofuoglu S C (2009) A health risk assessment for exposure to trace metals via drinking water ingestion pathway. Int J Hyg Environ Health 212(2):216-227. doi: 10.1016/j.ijheh.2008.05.002

32. Kükrer S, Mutlu E, (2019) Assessment of surface water quality using water quality index and multivariate statistical analyses in Saraydüzü Dam Lake, Turkey. Environ Monit Assess 191 (2):71. doi: 10.1007/s10661-019-7197-6

33. Kumar A, Taxak AK, Mishra S, Pandey R (2021) Long term trend analysis and suitability of water quality of River Ganga at Himalayan hills of Uttarakhand, India. Environ Technol Innov 22:2352-1864. https://doi.org/10.1016/j.eti.2021.101405

34. Kumar D, Malik DS, Kumar N, Gupta N, Gupta V (2020b) Spatial changes in water and heavy metal contamination in water and sediment of river Ganga in the river belt Haridwar to Kanpur. Environ Geochem Health 42:2059-2079. https://doi.org/10.1007/s10653-019-00471-8

35. Kumar M, Puri A (2012) A review of permissible limits of drinking water. Indian J Occup Environ Med 16(1):40-44. doi:10.4103/0019-5278.99696

36. Kumar P, Rautela A, Kesari V, Szlag D, Westrick J, Kumar S (2020a) Recent developments in the methods of quantitative analysis of microcystins. J Biochem Mol Toxicol 34(12):e22582. https://doi.org/10.1002/jbt.22582

37. Lkr A, Singh MR, Puro N (2020) Assessment of water quality status of Doyang River, Nagaland, India, using Water Quality Index. Appl Water Sci 10:46. https://doi.org/10.1002/jbt.22582

38. Mackintosh C, Beattie KA, Klumpp S, Cohen P, Codd GA (1990) Cyanobacterial microcystin-LR is a potent and specific inhibitor of protein phosphatase 1 and 2A from both mammals and higher plants. FEBS Lett 264:187-192. doi:10.1016/0014-5793(90)80245-e

39. Massey IW, Wu P, Wei J, Luo J, Ding P, Wei H, Yang F (2020) A Mini-Review on Detection Methods of Microcystins. Toxins 12:641. doi:10.3390/toxins12100641

40. Mateo P, Leganés F, Perona E, Loza V, Fernández-Piñas F (2015) Cyanobacteria as bioindicators and bioreporters of environmental analysis in aquatic ecosystems. Biodivers Conserv 24:909-948. doi:10.1007/s10531-015-0903-y

41. Matta G, Nayak A, Kumar A, Kumar P (2020) Water quality assessment using NSFWQI, OIP and multivariate techniques of Ganga River system, Uttarakhand, India. Appl Water Sci 10:206 https://doi.org/10.1007/s13201-020-01288-y

42. Matta G, Srivastava S, Pandey RR Saini KK (2017) Assessment of physicochemical characteristics of Ganga Canal water quality in Uttarakhand. Environ Dev Sustain 19:419-431. https://doi.org/10.1007/s10668-015-9735-x

Page 12/19 
43. McGowan W (2000) Water processing: residential, commercial, light-industrial, 3rd ed. Lisle, IL, Water Quality Association.

44. Medeiros AC, Faial KRF, do Carmo Freitas Faial K, da Silva Lopes ID, de Oliveira Lima M, Guimarães RM Mendonça NM (2017) Quality index of the surface water of Amazonian rivers in industrial areas in Pará, Brazil. Mar Pollut Bull 123(1-2):156-164. https://doi.org/10.1016/j.marpolbul.2017.09.002

45. Mikalsen B, Boison G, Skulberg OM, Fastner J, Davies W, Gabrielsen TM, Rudi K, Jakobsen KS (2003) Natural variation in the microcystin synthetase operon mcyABC and impact on microcystin production in Microcystis strains. J Bacteriol 185(9):2774-2785. doi: 10.1128/JB.185.9.2774-2785.2003

46. Mitra P, Pal DP, Das M (2018) Does quality of drinking water matter in kidney stone disease: A study in West Bengal, India? Investig Clin Urol 59(3):158165. doi:10.4111/icu.2018.59.3.158

47. Neilan BA, Pearson LA, Muenchhoff J, Moffitt MC, Dittmann E (2013) Environmental conditions that influence toxin biosynthesis in cyanobacteria. Environ Microbiol 15(5):1239-1253. doi: 10.1111/j.1462-2920.2012.02729.x.

48. Ouellette AJA, Handy SM, Wilhelm SW (2006) Toxic Microcystis is widespread in Lake Erie: PCR detection of toxin genes and molecular characterization of associated microbial communities. Microbiol Ecol 51:154-165. https://doi.org/10.1007/s00248-004-0146-z

49. Pandey J, Yadav A (2015) The Changing State of N: P: Si Stoichiometry in Ganga River: Possible Implications for Production and Fate of Phytoplankton Biomass. Water 6:91-99. doi: 10.14294/WATER.2015.1

50. Pandey M, Pandey AK, Mishra A, Tripathi BD. (2015) Assessment of metal species in river Ganga sediment at Varanasi, India using sequential extraction procedure and SEM-EDS. Chemosphere 134:466-474. doi:10.1016/j.chemosphere.2015.04.047

51. Pandey R, Raghuvanshi D, Shukla D (2014) Assessment of Physico-Chemical Parameters of River Ganga at Allahabad with respect To WQI. IJIRSET 9:16339-16349. doi:10.15680/IJIRSET.2014.0309076

52. Prasad S, Saluja R, Joshi V, Garg JK (2020) Heavy metal pollution in surface water of the Upper Ganga River, India: human health risk assessment. Environ Monit Assess 192:742. https://doi.org/10.1007/s10661-020-08701-8

53. Rahmanian N, Ali SHB, Homayoonfard M, Ali NJ, Rehan M, Sadef Y, Nizami AS (2015) Analysis of Physiochemical Parameters to Evaluate the Drinking Water Quality in the State of Perak, Malaysia. J Chem 2015:716125. https://doi.org/10.1155/2015/716125

54. Rai B (2013) Pollution and conservation of Ganga river in modern India. Int J Sci Res Pub 3: 2250-3153.

55. Rantala A, Fewer DP, Hisbergues M, Rouhiainen L, Vaitomaa J, Borner T, Sivonen K (2004) Phylogenetic evidence for the early evolution of microcystin synthesis: Proceedings of the National Academy of Science 101(2):568-573. doi:10.1073/pnas.0304489101

56. Rantala A, Rajaniemi-Wacklin P, Lyra C, Lepisto L, Rintala J, Mankiewicz-Boczek J, Sivonen K (2006) Detection of microcystin-producing cyanobacteria in Finnish lakes with genus-specific microcystin synthetase gene E (mcyE) PCR and associations with environmental factors. Appl Environ Microbiol 72(9):6101-6110. doi:10.1128/AEM.01058-06

57. Ribeiro MSF, Tucci A, Matarazzo MP, Viana-Niero C, and Nordi CSF (2020) Detection of Cyanotoxin-Producing Genes in a Eutrophic Reservoir (Billings Reservoir, São Paulo, Brazil). Water 12:903. doi:10.3390/w12030903

58. Romanis CS, Pearson LA, Neilan BA (2021) Cyanobacterial blooms in wastewater treatment facilities: Significance and emerging monitoring strategies. J Microbiol Methods 180 (2021) 106123. https://doi.org/10.1016/j.mimet.2020.106123

59. Sarkar SD, Naskar M, Gogoi P, Raman RK, Manna RK, Samanta S, Mohanty BP, Das BK (2019) Impact assessment of barge trafficking on phytoplankton abundance and Chl a concentration, in River Ganga, India. PLoS ONE 14(9): e0221451. https://doi.org/10.1371/journal.pone.0221451

60. Satya K, Narayan C (2018) Study of Physico-Chemical and Biological Characteristics of The Water of River Ganga at Patna, India. Curr World Environ 13(3). http://dx.doi.org/10.12944/CWE.13.3.10

61. Shukla N, Gupta MK, Chaurasia GL, Singh S, Singh SB, Shukla D.N., Srivastava V, Tandona PK (2015) A Study on Phytoplankton Diversity in River Ganga at Allahabad, Uttar Pradesh (India). Green Chem Technol Lett 1(1):92-95. https://doi.org/10.18510/gctl.2015.1115

62. Siddiqui E, Pandey J (2019) Temporal and spatial variations in carbon and nutrient loads, ion chemistry and trophic status of the Ganga River: a watershed-scale study. Limnology 20, 255-266. https://doi.org/10.1007/s10201-019-00575-1

63. Singh N (2010) Physico-chemical properties of polluted water of river Ganga at Varanasi. Int J Energy Environ 1(5):823-832.

64. Singh YV, Sharma PK, Meena R, Kumar M, Verma SK (2016) Physico-chemical analysis of river Ganga at Varanasi city in Uttar Pradesh, India. IJAAS 2(3):41-45.

65. Sinha RK, Kannan K (2014) Ganges river dolphin: An overview of biology, ecology, and conservation status in India. Ambio 43(8):1029-1046. doi:10.1007/s13280-014-0534-7

66. Son CT, Giang NTH, Thao TP, Nui NH, Lam NT, Cong VH (2020) Assessment of Cau River water quality assessment using a combination of water quality and pollution indices. J Water Supply: Res and Technol-Aqua 69 (2):160-172. doi: https://doi.org/10.2166/aqua.2020.122

67. Son JH, Kim S, Carlson KH (2015) Effects of wildfire on river water quality and riverbed sediment phosphorus. Water Air Soil Pollut 226(3):26. https://doi.org/10.1007/s11270-014-2269-2

68. Sreenivasan A (1964) Primary production in three uplond lake of Madras State. Curr Sci 32(3):130-135.

69. Srivastava AK, Ara A, Bhargava P, Mishra Y, Rai SP, Rai LC (2007) A rapid and cost-effective method of genomic DNA isolation from cyanobacterial culture, mat and soil suitable for genomic fingerprinting and community analysis. J Appl Phycol 19:373-382. https://doi.org/10.1007/s10811-006-9144-5

70. Tamura K, Stecher G, Peterson D, Filipski A, Kumar S (2013) MEGA6: molecular evolutionary genetics analysis version 6.0. Mol Biol Evol 30:2725-2729. doi: 10.1093/molbev/mst197

71. Tillett D, Dittmann E, Erhard M, von Döhren H, Börner T, Neilan BA (2000) Structural organization of microcystin biosynthesis in Microcystis aeruginosa PCC7806: an integrated peptide-polyketide synthetase system. Chem Biol 7:753-764. doi:10.1016/s1074-5521(00)00021-1

Page 13/19 
72. Tripathi M, Singal S K (2019) Use of Principal Component Analysis for parameter selection for development of a novel Water Quality Index: A case study of river Ganga India. Ecol Indic 96:430-436. https://doi.org/10.1016/j.ecolind.2018.09.025

73. Turner AD, Dhanji-Rapkova M, O'Neill A, Coates L, Lewis A, Lewis K (2018) Analysis of Microcystins in Cyanobacterial Blooms from Freshwater Bodies in England. Toxins (Basel) 10(1):39. doi:10.3390/toxins10010039

74. UPPCB (2019) River Water Quality-April 2019. (http://www.uppcb.com/pdf/water-quality-april_200519.pdf)

75. Verma AK, Saksena DN (2010) Impact of pollution on sewage collecting River Kalpi (Morar) Gwalior (M.P.) with special reference to water quality and Macro-zoobenthic fauna. Asian J Exp Biol Sci 1:155-161.

76. Wagner ND, Osburn FS, Wang J, Taylor RB, Boedecker AR, Chambliss CK, Brooks BW, Scott JT (2019) Biological stoichiometry regulates toxin production in Microcystis aeruginosa (UTEX 2385). Toxins 11(10):601. https://doi.org/10.3390/toxins 11100601

77. Wang S, Ding P, Lu S, Wu P, Wei X, Huang R, Kai T (2021) Cell density-dependent regulation of microcystin synthetase genes ( $m c y$ ) expression and microcystin-LR production in Microcystis aeruginosa that mimics quorum sensing. Ecotoxicol Environ Safety 220: 112330.

https://doi.org/10.1016/j.ecoenv.2021.112330

78. Wei J, Xie X, Huang F, Xiang L, Wang Y, Han T, Massey IY, Liang G, Pu Y, Yang F (2020) Simultaneous Microcystis algicidal and microcystin synthesis inhibition by a red pigment prodigiosin. Environ Pollut 256:113444. https://doi.org/10.1016/j.envpol.2019.113444

79. WHO (2011) Guidelines for Drinking-water Quality, 4th ed. WHO, Geneva, Switzerland.

80. Zhang S, Du X, Liu H, Losiewic MD, Chen X, Ma Y, Wang R, Tian Z, Shi L, Guo H, Zhang H (2021) The latest advances in the reproductive toxicity of microcystin-LR. Environ Res 192:110254. https://doi.org/10.1016/j.envres.2020.110254

\section{Figures}

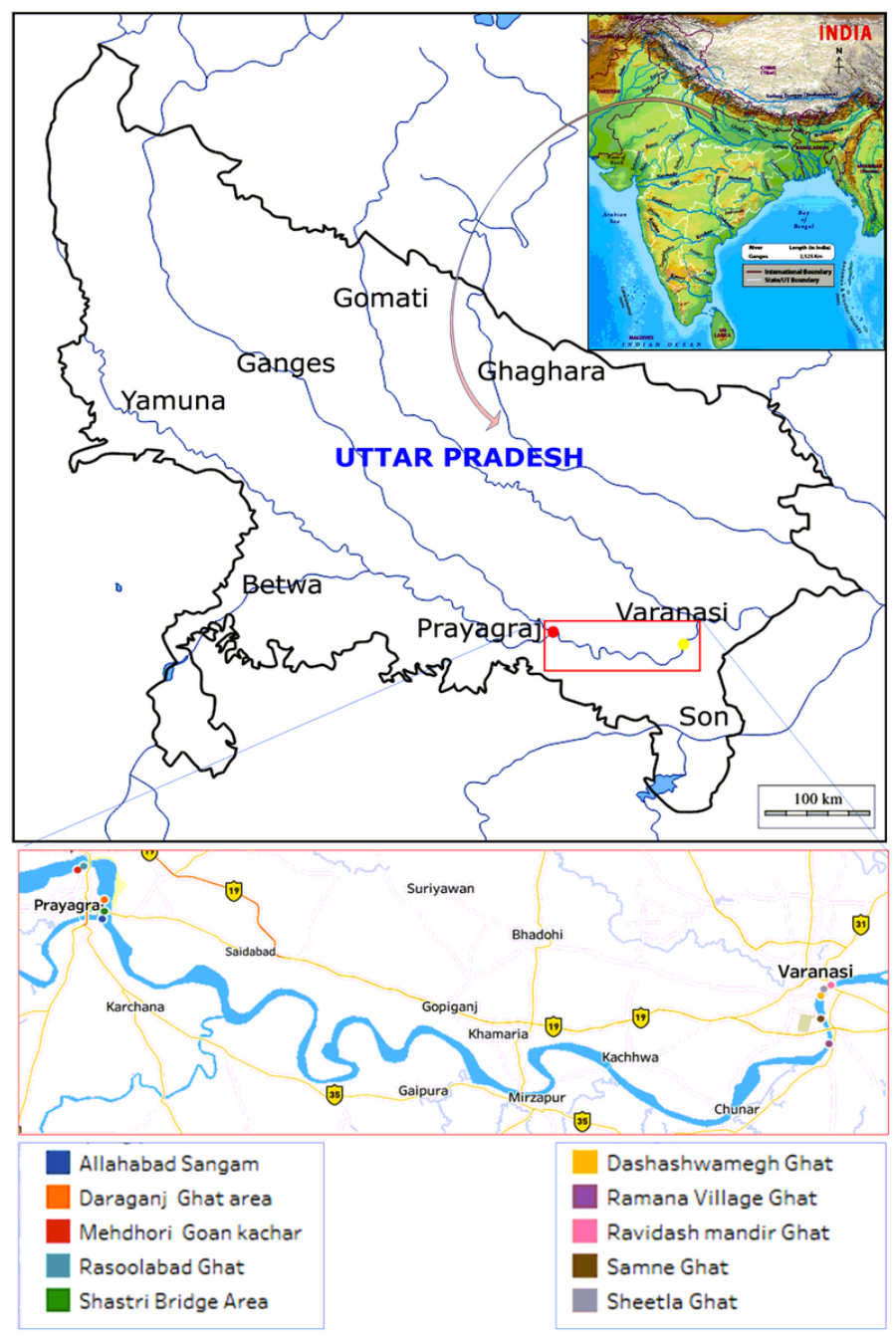

\section{Figure 1}

Map of the river Ganga from Prayagraj to Varanasi regions of Uttar Pradesh, India showing the 10 sampling points at the study site. 


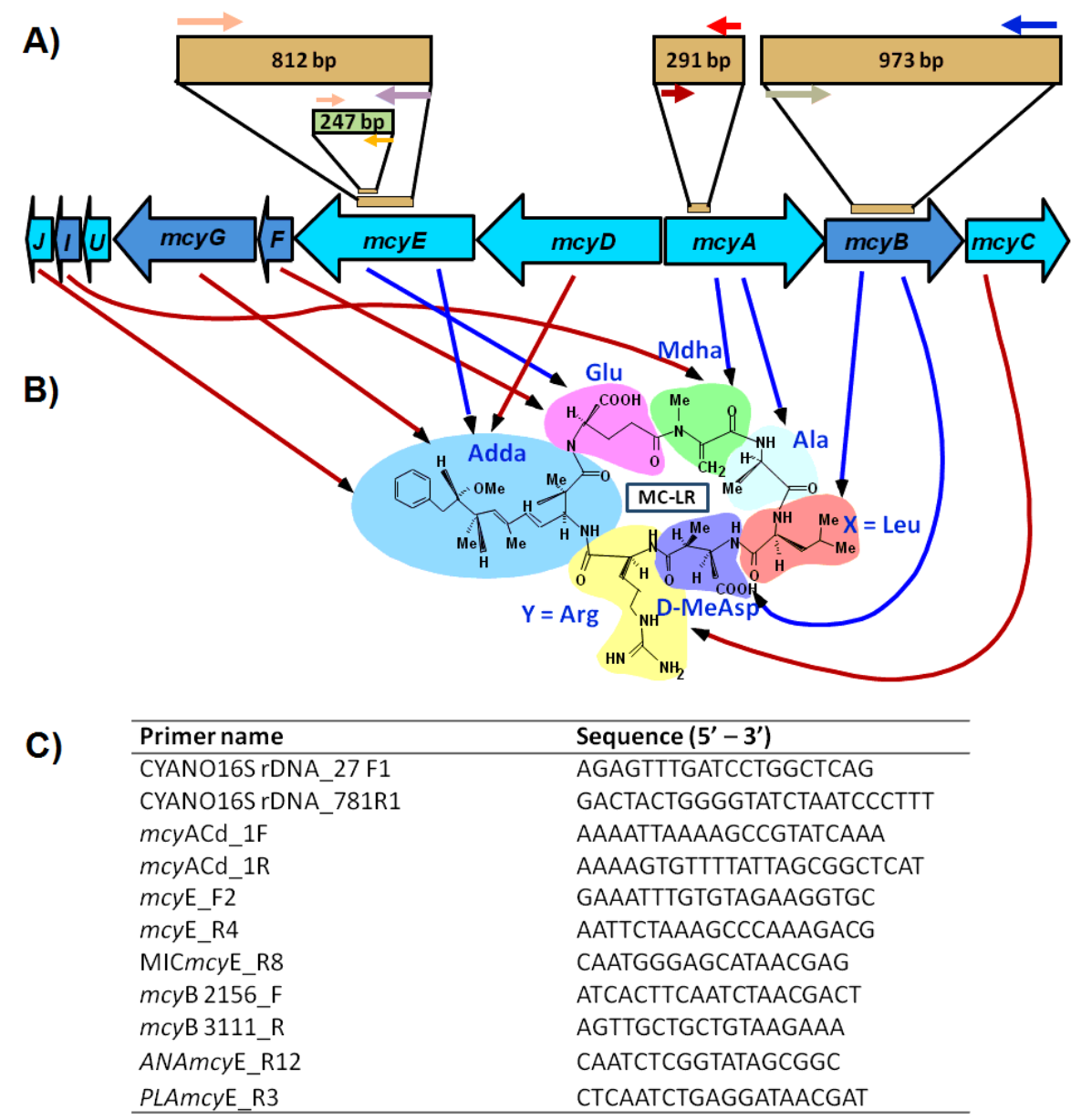

Figure 2

Primers and stratergy used for the detection of microcystin synthetase (mcy) genes possessing cyanobacteria in the phytoplanktonic water samples of river Ganga at 10 sampling points of Prayagraj to Varanasi. A) Schematic arrangement of the 10 genes mcyA-J in MC operon. B) Structure of cyanobacterial heptapeptide heptatoxins MC-LR [cyclo-(D-Ala-X-D-MeAsp-Y-Adda-D-Glu-Mdha)]; X, L=leucine; Y, L=arginine; Me=CH3; D-MeAsp=D-erythro- $\beta$-methylaspartic

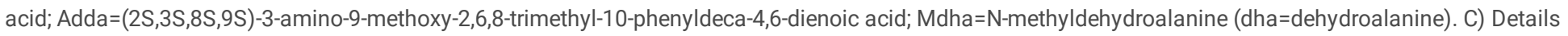
of primers used in the study. 


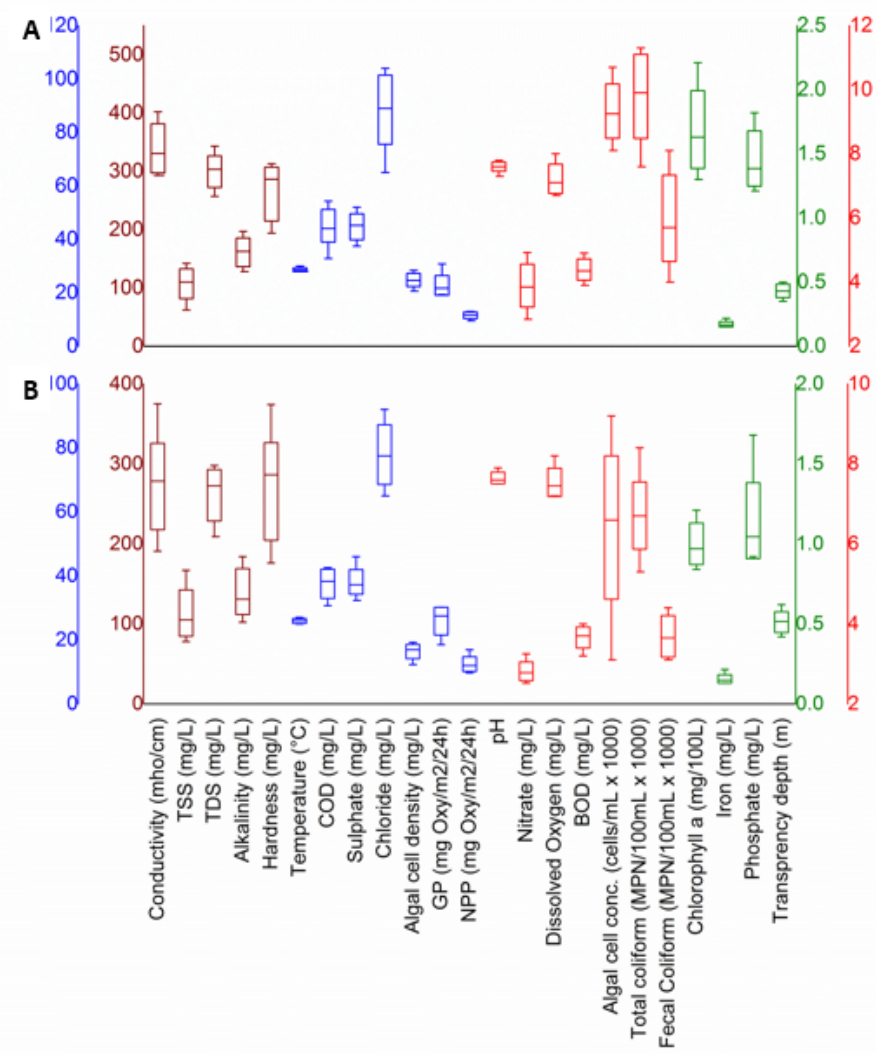

Figure 3

Box and whisker plot represents the spatial variation in various physico-chemical and biological parameters of Ganga water at 10 different study sites of Prayagraj and Varanasi during A) June 2017 and B) March 2018. GP- Gross Productivity; NPP- Net Primary Productivity 

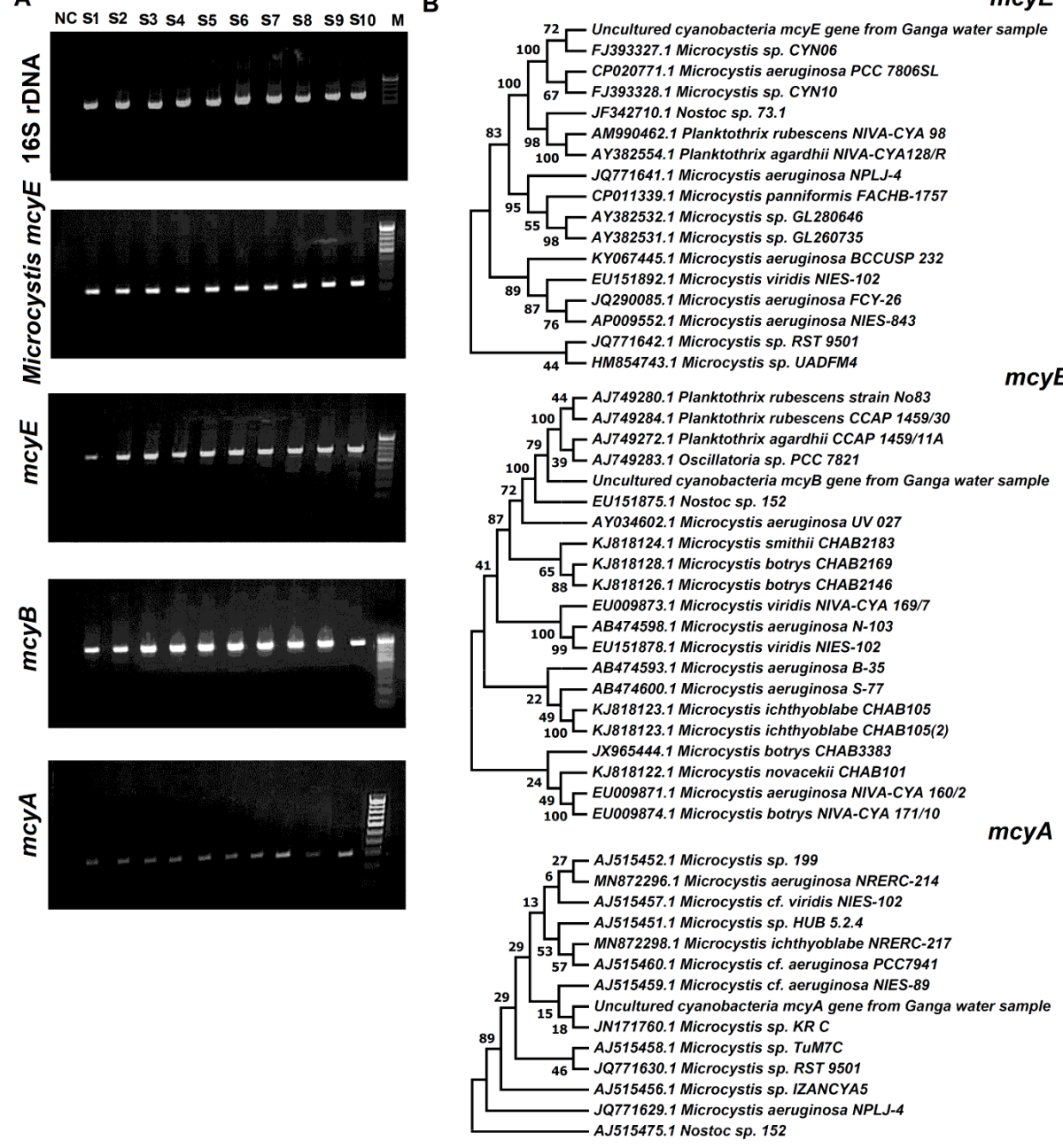

Figure 4

A) PCR amplification of 16S rDNA and microcystin synthetase (mcy) genes of uncultured cyanobacteria in phtyoplanktonic water samples of river Ganga collected from 10 different sampling sites of Prayagraj and Varanasi. (NC-negative control, S1-Allahabad Sangam, S2-Daraganj Ghat area, S3-Mehdhori Gaon Kachar, S4-Rasoolabad Ghat, S5-Shastri Bridge area, S6 -Dashaswamegh Ghat, S7-Ramana Village, S8-Ravidash mandir Ghat, S9-Samne Ghat, S10-Sheetla Ghat, M - Marker). B) The evolutionary history was inferred based on mcyA, mcyE and mcyB gene sequences using the NJ method. The bootstrap consensus tree inferred from 1000 replicates is taken to represent the evolutionary history of the taxa analyzed. The evolutionary distances were computed using the Kimura 2-parameter method. Evolutionary analyses were conducted in MEGA6 software (Tamura et al., 2013). 


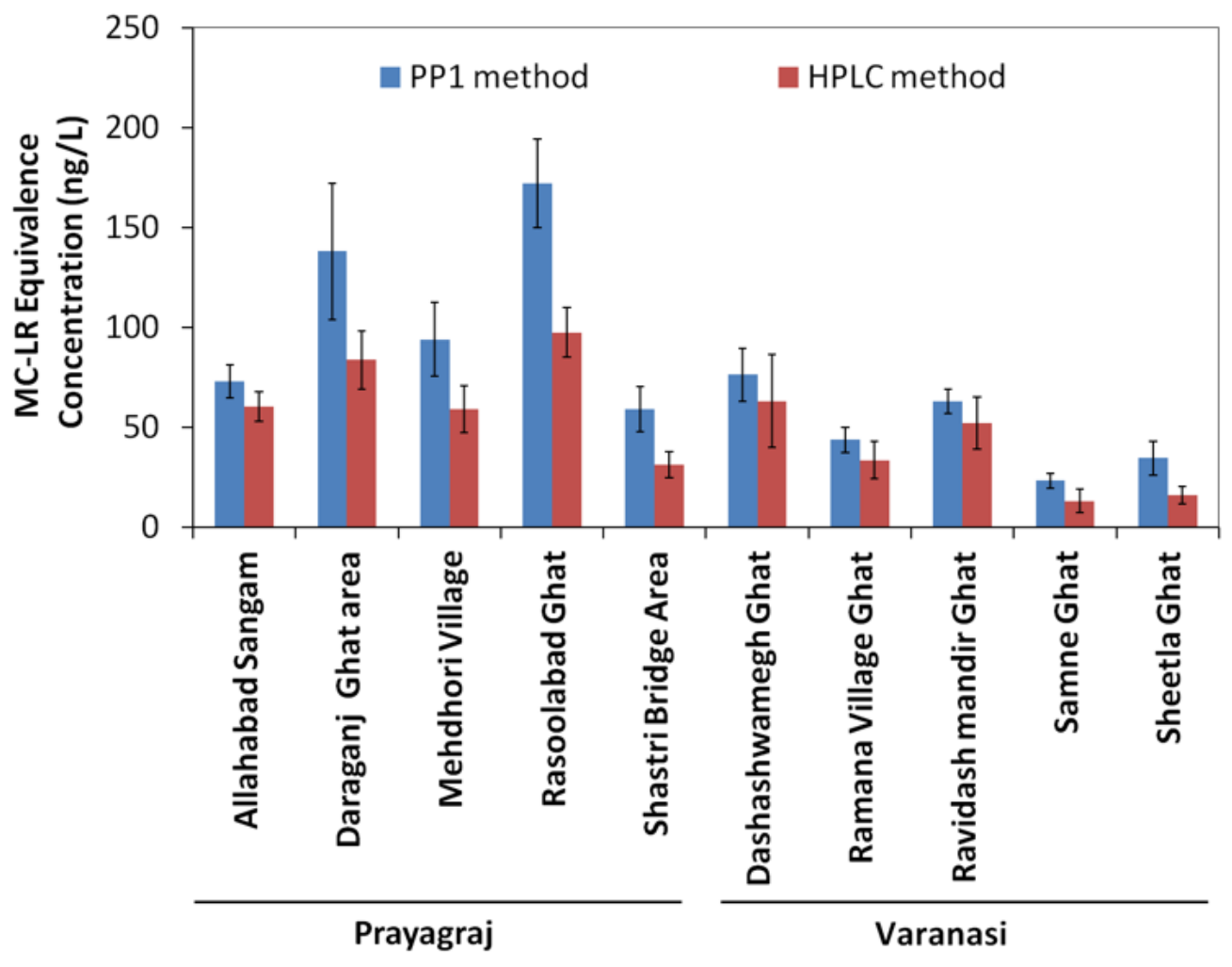

Figure 5

Concentration of Microcystin-LR equivalence detected by PP1 inhibition assay and HPLC method in the river Ganga water samples collected during March 2018 from 10 different sampling sites of Prayagraj and Varanasi regions.

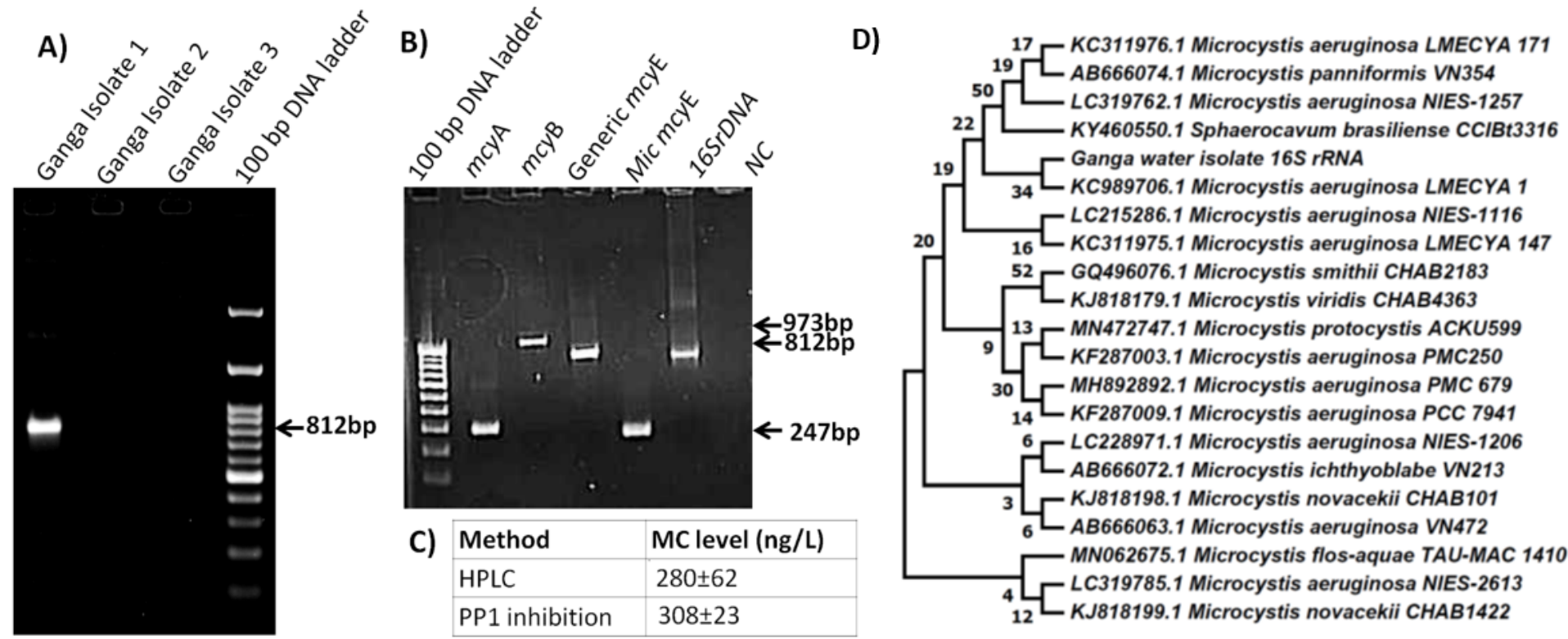

Figure 6

PCR amplification of A) generic mcyE gene from three different Ganga isolate, B) 16s rDNA and microcystin synthase (mcy) genes from Ganga isolate 1, C) microcystin-LR concentartion by Ganga isolate 1 and D) The evolutionary history was inferred based on partial 16S rDNA sequence of Ganga isolate 1 using the NJ method. The bootstrap consensus tree inferred from 1000 replicates is taken to represent the evolutionary history of the taxa analyzed. The evolutionary distances were computed using the Kimura 2-parameter method. Evolutionary analyses were conducted in MEGA6 software (Tamura et al., 2013). 
This is a list of supplementary files associated with this preprint. Click to download.

- Supplementaryfigurefinal.docx

Page 19/19 